\title{
Molecular and Pathotypic Characterization of New Xanthomonas oryzae Strains from West Africa
}

\author{
Carolina Gonzalez, ${ }^{1}$ Boris Szurek, ${ }^{1}$ Charles Manceau, ${ }^{2}$ Thierry Mathieu, ${ }^{1}$ Yacouba Séré,${ }^{3}$ and \\ Valérie Verdier ${ }^{1}$ \\ ${ }^{1}$ Laboratoire Génome et Développement des Plantes, IRD-CNRS-Université de Perpignan, Centre IRD, 911Av Agropolis, \\ BP64501, 34394 Montpellier, France, ${ }^{2}$ UMR de Pathologie Végétale, INRA, Station de Pathologie Végétale, 42 rue Georges \\ Morel, BP57, 49071 Beaucouzé Cedex, France, ${ }^{3}$ WARDA-The Africa Rice Center, Cotonou, Bénin
}

Received 11 September 2006. Accepted 26 November 2006.

DNA polymorphism analysis and pathogenicity assays were used to characterize strains of Xanthomonas oryzae pv. oryzae and Xanthomonas oryzae pv. oryzicola collected from rice leaves in West Africa. Restriction fragment length polymorphism (RFLP), repetitive sequence-based polymerase chain reaction, fluorescent amplified fragmentlength polymorphism (FAFLP) analyses were assessed for molecular characterization, while pathogenicity was tested by leaf clipping and leaf infiltration. Dendrograms were generated for the data sets obtained from RFLP analysis and repetitive polymerase chain reaction suggesting that the interrelationships between strains were dependent on the technique used. In all cases, data showed that African strains of $X$. oryzae pv. oryzae form a group genetically distant from Asian strains. FAFLP analyses separated the $X$. oryzae strains into three groups with significant bootstrap values. A specific and intriguing feature of African strains of $X$. oryzae pv. oryzae is a reduction in the number of insertion sequence elements and transcription activator-like (avrBs3/pthA) effector genes, based on the molecular markers employed in the study. In addition, pathogenicity assays conducted with African strains of $X$. oryzae pv. oryzae on a series of nearly isogenic lines (NILs) identified three new races. Finally, leaf infiltration assays revealed the capacity of African strains of $X$. oryzae pv. oryzae to induce a nonhost hypersensitive response in Nicotiana benthamiana, in contrast with Asian X. oryzae pv. oryzae and X. oryzae pv. oryzicola strains. Our results reveal substantial differences between genomic characteristics of Asian and African strains of X. oryzae pv. oryzae.

Two important diseases of rice are due to Xanthomonas oryzae pathovars, bacterial blight (BB) caused by Xanthomonas oryzae pv. oryzae and bacterial leaf streak (BLS) caused by Xanthomonas oryzae pv. oryzicola. These two phytopathogenic bacteria are highly related, showing more than $90 \%$ similarity by the DNA:DNA hybridization and are difficult to differentiate genetically and phenotypically (Rademaker et al. 2000; Swings et al. 1990). Indeed, the symptoms provoked by $X$. oryzae pv. oryzae and $X$. oryzae pv. oryzicola are different at early but not later stages of infection (Niño-Liu et al. 2006). They infect their host in distinct ways; $X$. oryzae pv. oryzae enters through hydathodes and spreads systemically through the xylem, while $X$. oryzae pv. oryzicola, which is a nonvascu-

Corresponding author: V. Verdier; Telephone:+33 4 67416212; Fax:+33 4 67416181; E-mail: verdier@mpl.ird.fr lar pathogen, enters through stomata and colonizes the mesophyll parenchyma (Niño-Liu et al. 2006). Bacterial blight is a major disease in rice-irrigated environments, causing a substantial yield loss of up to $50 \%$ in severe epidemics (Ou et al. 1985). BB has been reported in Asia, Australia, and Latin America (Mew et al. 1993) and is emerging in importance in Africa, as briefly reported by Ryba-White and associates (1995). BLS is increasing in importance in areas of Asia where hybrid rice is widely grown (Raymundo et al. 1999). The disease was also reported in Madagascar, Nigeria, and Senegal (Buddenhagen 1985). Although both diseases were reported earlier in Africa, a detailed molecular and pathotypic analysis of $X$. oryzae pv. oryzae and $X$. oryzae pv. oryzicola strains was still lacking until this study. Sustainable control measures for BB and BLS in Africa, however, will depend on parallel improvements in the understanding of the pathogen population structure and evolution and on the analysis of microbial genes involved in the interaction.

Numerous studies have been carried out on the rice- $X$. oryzae pv. oryzae pathosystem, resulting in powerful advancement in the understanding of the molecular basis of the interaction (Shen and Ronald 2002). The rice-X. oryzae pv. oryzae interaction follows the classical gene-for-gene model. As a prerequisite for designing breeding strategies to control bacterial blight disease, a comprehensive study of $X$. oryzae pv. oryzae pathogen diversity was conducted in different Asian countries. Pathogen populations of $X$. oryzae pv. oryzae are highly variable, as revealed by virulence and DNA fingerprinting analysis (Adhikari et al. 1995, 1999; Leach et al. 1992; Nelson et al.1994). A race or pathotype is a group of strains sharing common phenotype of virulence to a set of host cultivars. Over thirty $X$. oryzae pv. oryzae races have been reported in Asia, and new ones have emerged to overcome deployed resistance (Adhikari 1994; Jeung et al. 2006; Nelson et al. 1994; Niño-Liu et al. 2006; Noda et al. 1996; Vera Cruz et al. 2000). Adaptation to rice varieties containing a single dominant resistance gene often results from the loss of function of the corresponding pathogen avr gene. Consequently, the durability and quality of a resistance gene is a function of the amount of fitness penalty imposed on the pathogen (Vera Cruz et al. 2000).

Host resistance is considered to be a sound approach to control $\mathrm{BB}$, although major resistance genes are not durable because of the high degree of pathogenic variation exhibited by $X$. oryzae pv. oryzae (Vera Cruz et al. 2000). Durable resistance is more likely to be achieved through pyramiding different types of resistance $(R)$ genes ( $\mathrm{Li}$ et al. 2006). Currently, various rice genes conferring resistance to $X$. oryzae pv. oryzae have been identified genetically and designated in a 
series from $\mathrm{Xal}$ to $\mathrm{Xa29}$, of which nine were identified as recessively inherited. So far, six $R$ genes (Xa1, xa5, xa13, $X a 21, X a 26$, and Xa27) have been characterized as encoding different types of proteins, suggesting multiple mechanisms of $R$ gene-mediated $X$. oryzae pv. oryzae resistance (Chu et al. 2006; Gu et al. 2005; Iyer and Couch 2004; Song et al. 1995; Sun et al. 2004; Yoshimura et al. 1998). Various polymerase chain reaction (PCR)-based markers were developed for $\mathrm{Xa}$ genes, providing powerful tools for marker-assisted selection of $R$ genes in breeding programs. Major genes of resistance have been incorporated into rice varieties to develop BB-resistant varieties and to build near-isogenic lines (NILs) (Ogawa et al. 1991).

The population structure of the BLS pathogen X. oryzae pv. oryzicola has been little studied, except in the Philippines where a high diversity was observed among strains (Raymundo et al. 1999). Haplotypes were characterized allowing further selection of a set of strains for resistance analysis. Resistance to BLS is believed to be quantitative; however, no resistance genes against $X$. oryzae pv. oryzicola have been characterized in rice so far (Zhao et al. 2004a). Recently, maize single dominant gene Rxol was identified for its property to mediate a nonhost defense response to $X$. oryzae pv. oryzicola (Zhao et al. 2004b). Rxol also prevents the development of BLS when it is expressed as a transgene in rice (Zhao et al. 2005).

$X$. oryzae pv. oryzae pathogenicity is highly dependent on a type III secretion system (T3SS) injecting effector proteins into the eukaryotic host cell (Buttner and Bonas 2002). Most of our knowledge on T3SS effectors in X. oryzae pv. oryzae is based on studies of the large AvrBs3/PthA family of Xanthomonas effector proteins, the abundance of which in individual strains is a unique feature of Xanthomonas oryzae pathovars as compared with other Xanthomonas spp. (Ochiai et al. 2005). Also referred to as transcription activator-like (TAL) effectors, this family includes proteins with avirulence activities, virulence functions, or both (Gurlebeck et al. 2006). Among them are avrXa7, avrXa10, avrxa5, and avrXa27, which have been cloned from $X$. oryzae pv. oryzae Philippine strains and which all exhibit resistance gene-specific avirulence function ( $\mathrm{Gu}$ et al. 2005; Hopkins et al. 1992). In addition to the well-characterized AvrXa7 protein (Yang et al. 2000), new TAL effectors were recently reported to be major virulence determinants (Yang and White 2004). Analysis of the genome sequences of the $X$. oryzae pv. oryzae Korean KACC10331 and Japanese MAFF311018 strains enabled the identification of a few other T3SS effector candidates, including $a v r B s 2, h p a F$, and popClike genes (Lee et al. 2005; Ochiai et al. 2005). Isolated from $X$. oryzae pv. oryzicola BLS256, avrRxol encodes the corresponding avirulence protein that was reported to be associated with the plasma membrane and to interact with Rxol inside maize cells to elicit cell death (Zhao et al. 2004a). This novel effector gene, the action of which is T3SS-dependent, is not related to TAL effector genes but is conserved in all $X$. oryzae pv. oryzicola strains tested so far, suggesting that it may act as a critical fitness or virulence factor, or both.

Well-developed genetic tools together with reproducible inoculation methods and the availability of rice NILs provide good support for analyses of Xanthomonas oryzae pathovar strains. We report here on the characterization of Xanthomonas oryzae strains in West Africa.

\section{RESULTS}

\section{Identification of three new $X$. oryzae pv. oryzae races} among African strains.

A total of 96 severely blighted leaves of different African cultivars were collected in three West African countries (Mali,
Niger, and Burkina Faso) and were processed for bacterial isolation. A total of $26 \mathrm{X}$. oryzae strains were isolated and are referred to here as field isolates. These 26 field isolates together with selected strains of $X$. oryzae pv. oryzae and $X$. oryzae pv. oryzicola obtained from international collections were then evaluated for virulence by leaf-clip inoculation on the rice variety Nipponbare. Typical BB symptoms were visible for 16 field isolates (MAI1, MAI2, and MAI9, BAI1 to BAI4, and NAI1 to NAI9) and were similar to those observed upon inoculation of $X$. oryzae pv. oryzae Asian strains PXO339, PXO71, and CFBP1949, i.e., chlorotic regions in leaf tissue spreading from the leaf tip toward the leaf base and forming lesions $>15 \mathrm{~cm}$. Ten field isolates (MAI3 to MAI8 and MAI10 to MAI13) did not induce any symptoms, nor did $X$. oryzae pv. oryzicola strains BLS256, UPB497, or CFBP2286 (Table 1). Syringe infiltration of all these strains also resulted in two different types of reaction, as exemplified for field isolates BAI4 and MAI3 in Figure 1. Localized lesions at the inoculation point were observed for the above-mentioned 16 isolates (MAI1, MAI2, and MAI9, BAI1 to BAI4. NAI1 to NAI9) and reference strains $X$. oryzae pv. oryzae PXO339, PXO71, and CFBP1949 (Fig. 1 and Table 1). In contrast, the ten other isolates (MAI3 to MAI8 and MAI10 to MAI13) together with reference $X$. oryzae pv. oryzicola strains induced typical BLS water-soaking lesions visible by day 5, developing into yellow translucent lesions with droplets of bacterial exudates by day 10 (Fig. 1). The average size of the yellow translucent lesions varied among the isolates. One-way analysis of variance (ANOVA) revealed significant effects of isolates $(F=$ 82.74; $P<10^{-4}$ ) that were grouped in four classes (A to D). Therefore and for simplicity, we referred to the field isolates inducing typical BB symptoms as $X$. oryzae pv. oryzae (strains MAI1, MAI2, and MAI9, BAI1 to BAI4, NAI1 to NAI9) and the ones inducing typical BLS symptoms as $X$. oryzae pv. oryzicola (strains MAI3 to MAI8 and MAI10 to MAI13; Table 1).

The $16 X$. oryzae pv. oryzae African strains, together with control $X$. oryzae pv. oryzae strains corresponding to different Phillipine races (from the International Rice Research Institute [IRRI] collection) and African X. oryzae pv. oryzae strains isolated in 1980 (Collection Française de Bactéries Phytopathogènes $[\mathrm{CFBP}])$ were next evaluated for virulence on a series of 10 NILs, each carrying a single $(\mathrm{Xa})$ resistance gene. As shown in Table 2, three races (A1, A2, and A3) were thereby characterized. Race A1 strains isolated in Cameroon, Niger, and Burkina are incompatible on IRBB4, IRBB5, and IRBB7 lines and showed a moderately susceptible reaction on IRBB8 and IRBB21 lines. Race A2 consists of one strain (BAI4), which was isolated in Burkina on Oryza glaberrima and is incompatible on almost all IRBB lines tested, except for line IR24. Race A3 strains, which were exclusively isolated in Mali in 1980 and 2003, are incompatible on all IRBB lines tested, including IR24. The $X$. oryzae pv. oryzae Phillipine races tested showed different reactions on the IRBB lines (Table 1 and data not shown) and confirmed previous results (Ogawa et al. 1991; Nelson et al. 1994).

\section{$X$. oryzae pv. oryzae African strains induce a nonhost hypersensitive response (HR) in Nicotiana benthamiana.}

Next, we addressed the question of whether high-titer inoculation of $N$. benthamiana leaves with African and reference Asian Xanthomonas oryzae strains of both pathovars would help in discriminating our strains, upon scoring of potential nonhost HR induction. All X. oryzae pv. oryzae African strains induced a typical nonhost cell-death response $48 \mathrm{~h}$ postinoculation in $N$. benthamiana, while none of the $X$. oryzae pv. oryzae Asian ones did (Fig. 2 and Table 1). In contrast, no 
Table 1. Characteristics of the Xanthomonas oryzae strains used in this study

\begin{tabular}{|c|c|c|c|c|c|c|c|c|c|c|c|c|}
\hline \multirow[b]{2}{*}{ Strains ${ }^{c}$} & \multirow[b]{2}{*}{ Origin $^{d}$} & \multicolumn{4}{|c|}{ Pathogenicity assays } & \multicolumn{4}{|c|}{ RFLP' } & \multicolumn{2}{|c|}{ Rep-PCR } & \multirow[b]{2}{*}{ AFLP } \\
\hline & & A & B & $\mathrm{C}$ & D & PJEL101 & avrXalo & Tnx 1 & Xoo1762 & Rep & Eric & \\
\hline \multicolumn{13}{|c|}{ Xanthomonas oryzae pv. oryzae } \\
\hline A 3842 & India & nt & $\mathrm{nt}$ & nt & nt & $1^{n}$ & $1^{m t}$ & $1^{\prime \prime}$ & nt & $1^{t}$ & $1^{\sigma}$ & nt \\
\hline A 3857 & India & $\mathrm{nt}$ & $\mathrm{nt}$ & $\mathrm{nt}$ & nt & $2^{\text {eil }}$ & $2^{m r}$ & $2^{\prime \prime}$ & $1^{\infty}$ & $2^{r}$ & $1^{\sigma}$ & nt \\
\hline HN35 & Chine & nt & $\mathrm{nt}$ & nt & nt & $3^{\text {il }}$ & $3^{m+r}$ & $3^{\prime \prime \prime}$ & nt & $3^{r}$ & $2^{\alpha}$ & 1 \\
\hline IXO57 & Indonesia & $\mathrm{nt}$ & $\mathrm{nt}$ & $\mathrm{nt}$ & $\mathrm{nt}$ & $4^{m i}$ & $4^{\prime \prime \prime}$ & $4^{\prime \prime}$ & $2^{\circ}$ & $4^{\prime}$ & $2^{\sigma}$ & $\mathrm{nt}$ \\
\hline IXO60 & Indonesia & $\mathrm{nt}$ & $\mathrm{nt}$ & $\mathrm{nt}$ & $\mathrm{nt}$ & $5^{n}$ & $4^{m r r}$ & $5^{\prime \prime}$ & $\mathrm{nt}$ & 5 & $2^{\sigma}$ & 1 \\
\hline MB 18 & Malaysia & $\mathrm{nt}$ & $\mathrm{nt}$ & $\mathrm{nt}$ & $\mathrm{nt}$ & $6^{8}$ & $5^{2 x t}$ & $3^{\prime \prime}$ & $3^{\circ}$ & 6 & $2^{\prime \prime}$ & 1 \\
\hline $\mathrm{MXO} 92$ & Malaysia & $\mathrm{nt}$ & $\mathrm{nt}$ & $\mathrm{nt}$ & $\mathrm{nt}$ & $7^{\text {ei }}$ & $6^{m t}$ & 5 & nt & 7 & $3^{\prime \prime}$ & nt \\
\hline NXO537 & Nepal & $\mathrm{nt}$ & $\mathrm{nt}$ & $\mathrm{nt}$ & $\mathrm{nt}$ & $8^{i}$ & $7^{m t}$ & $6=$ & $\mathrm{nt}$ & $8^{r}$ & $4^{\alpha}$ & 1 \\
\hline NXO622 & Nepal & $\mathrm{nt}$ & $\mathrm{nt}$ & $\mathrm{nt}$ & $\mathrm{nt}$ & $9^{\prime \prime}$ & $8^{2 x t}$ & $2^{\prime \prime}$ & nt & $9^{\prime}$ & $2^{\prime \prime}$ & nt \\
\hline $\mathrm{XOO} 212$ & Korea & $\mathrm{nt}$ & $\mathrm{nt}$ & $\mathrm{nt}$ & nt & $10^{81}$ & $4^{m r}$ & $6^{\prime \prime}$ & $1^{\infty}$ & $10^{\prime}$ & $4^{x}$ & 1 \\
\hline PXO61 & Philippines & + & $\mathrm{nt}$ & 1 & $\mathrm{nt}$ & $11^{n i}$ & $9^{m t r}$ & $7^{m}$ & $\mathrm{nt}$ & $11^{r}$ & $5^{*}$ & nt \\
\hline PXO71 (CFBP1946) & Philippines & + & a & 4 & - & $12^{n i}$ & $10^{m+t}$ & 7 & $\mathrm{nt}$ & $11^{\prime}$ & $6^{\prime \prime}$ & $\mathrm{nt}$ \\
\hline PXO79 (CFBP1981) & Philippines & + & $\mathrm{nt}$ & $3 B$ & $\mathrm{nt}$ & nt & $\mathrm{nt}$ & $\mathrm{nt}$ & $\mathrm{nt}$ & $\mathrm{nt}$ & $\mathrm{nt}$ & $\mathrm{nt}$ \\
\hline PXO86 & Philippines & + & $\mathrm{nt}$ & 2 & $\mathrm{nt}$ & $13^{n}$ & $11^{\mathrm{met}}$ & $8^{\prime \prime}$ & $\mathrm{nt}$ & $12^{\prime}$ & $\tau$ & $\mathrm{nt}$ \\
\hline PXO99 & Philippines & + & $\mathrm{nt}$ & 6 & $\mathrm{nt}$ & $14^{n i}$ & $12^{\mathrm{mt}}$ & $9^{m}$ & $\mathrm{nt}$ & $13^{\prime}$ & $8^{\alpha}$ & $\mathrm{nt}$ \\
\hline PXOI12 & Philippines & + & $\mathrm{nt}$ & 5 & $\mathrm{nt}$ & $15^{n}$ & $13^{\mathrm{met}}$ & $10^{\prime \prime \prime}$ & $\mathrm{nt}$ & $14^{r}$ & $8^{*}$ & nt \\
\hline PXO145 & Philippines & + & $\mathrm{nt}$ & 7 & $\mathrm{nt}$ & $16^{n}$ & $14^{m+1}$ & $11^{\mathrm{m}}$ & $\mathrm{nt}$ & $12^{\prime}$ & $7^{\prime \prime}$ & $\mathrm{nt}$ \\
\hline PXO280 & Philippines & + & $\mathrm{nt}$ & 8 & $\mathrm{nt}$ & $16^{n}$ & $9^{m i r}$ & $12^{=}$ & $\mathrm{nt}$ & $15^{x}$ & $7^{*}$ & $\mathrm{nt}$ \\
\hline PXO339 & Philippines & + & a & 9 & - & $17^{* i}$ & $15^{m+1}$ & $13^{\mathrm{m}}$ & $1^{\infty}$ & $16^{\prime}$ & $5^{\prime \prime}$ & 1 \\
\hline PXO340 & Philippines & + & $\mathrm{nt}$ & $3 \mathrm{C}$ & $\mathrm{nt}$ & $17^{i}$ & $16^{\mathrm{mt}}$ & $13^{\mathrm{m}}$ & nt & $16^{\prime}$ & $5^{\prime \prime}$ & $\mathrm{nt}$ \\
\hline PXO341 & Philippines & + & $\mathrm{nt}$ & 10 & $\mathrm{nt}$ & $17^{n i}$ & $17^{m t}$ & $13^{\mathrm{in}}$ & $\mathrm{nt}$ & $16^{\prime}$ & $5^{\alpha}$ & nt \\
\hline PXO345 & Philippines & + & $\mathrm{nt}$ & $9 \mathrm{c}$ & nt & $18^{n i}$ & $18^{m+t}$ & $13^{\mathrm{m}}$ & nt & $\mathrm{nt}$ & $\mathrm{nt}$ & $\mathrm{nt}$ \\
\hline PXO448 & Philippines & + & $\mathrm{nt}$ & $9 \mathrm{~b}$ & $\mathrm{nt}$ & $19^{i j}$ & $18^{\mathrm{mt}}$ & $14^{11}$ & $\mathrm{nt}$ & $\mathrm{nt}$ & $\mathrm{nt}$ & $\mathrm{nt}$ \\
\hline CFBP $2532 *$ (NCPPB3002) & India & + & $\mathrm{nt}$ & nt & nt & $20^{8 i}$ & $19^{m t}$ & $9^{m}$ & $4^{\circ}$ & $13^{r}$ & $9^{\pi}$ & 1 \\
\hline CIAT 1185 (LMG634) & Colombia & + & $\mathrm{nt}$ & $\mathrm{nt}$ & $\mathrm{nt}$ & $21^{n}$ & $20^{m t}$ & $15^{\prime \prime}$ & $\mathrm{nt}$ & $14^{\prime}$ & $7^{*}$ & $\mathrm{nt}$ \\
\hline CIAT 1186 (LMG635) & Colombia & + & $\mathrm{nt}$ & $\mathrm{nt}$ & $\mathrm{nt}$ & $22^{n i}$ & $20^{m+1}$ & $16^{\prime \prime}$ & $\mathrm{nt}$ & $11^{\prime}$ & $5^{\prime \prime}$ & $\mathrm{nt}$ \\
\hline CFBP 1948 (LMG12465) & Cameroon & + & $\mathrm{nt}$ & Al & $\mathrm{nt}$ & $23^{n}$ & $21^{m t}$ & $\mathrm{nh}$ & $\mathrm{nt}$ & $17^{\prime}$ & $10^{\prime}$ & $\mathrm{nt}$ \\
\hline CFBP1947 (LMG12464) & Cameroon & + & $\mathbf{a}$ & Al & $\mathrm{nt}$ & $23^{n}$ & $21^{m+t}$ & nh & $\mathrm{nt}$ & $17^{r}$ & $10^{r}$ & nt \\
\hline CFBP1949 (LMG12466) & Mali & + & a & A3 & nt & $23^{n i}$ & $21^{m t}$ & nh & $\mathrm{nt}$ & $17^{r}$ & $11^{* \pi}$ & 2 \\
\hline CFBP1951 (LMG12467) & Mali & + & $\mathrm{a}$ & A3 & nt & $23^{n}$ & $21^{\mathrm{mt}}$ & nh & $\mathrm{nt}$ & $17^{t}$ & $12^{\pi}$ & $\mathrm{nt}$ \\
\hline CFBPI952 (LMG12468) & Mali & + & a & A3 & $\mathrm{nt}$ & $23^{\text {ri }}$ & $21^{m \pi}$ & nh & nt & $17^{r}$ & $12^{\pi}$ & $\mathrm{nt}$ \\
\hline BAII & Burkina, Bagre & + & a & Al & + & $23^{n}$ & $22^{m+1}$ & $\mathrm{nh}$ & nt & $18^{\prime}$ & $13^{\pi}$ & $\mathrm{nt}$ \\
\hline $\mathrm{BAI} 2$ & Burkina, Bagre & + & a & Al & + & $23^{n}$ & $23^{\mathrm{mt}}$ & $\mathrm{nh}$ & $\mathrm{nt}$ & $18^{\prime}$ & $13^{\prime \prime}$ & $\mathrm{nt}$ \\
\hline BAI3 & Burkina, Bagre & + & a & Al & + & $23^{n}$ & $23^{m / 1}$ & nh & $5^{\circ}$ & $18^{r}$ & $13^{\text {r }}$ & 2 \\
\hline BAI4 & Burkina, Bagre & + & $\mathbf{a}$ & A2 & + & $23^{N}$ & $21^{m+m}$ & $\mathrm{nh}$ & $5^{\circ}$ & $18^{\prime}$ & $13^{\prime \prime}$ & $\mathrm{nt}$ \\
\hline NAIl & Niger, Saga & + & $\mathrm{a}$ & Al & + & $23^{n i}$ & $24^{m+t}$ & nh & $\mathrm{nt}$ & $18^{r}$ & $13^{\text {er }}$ & nt \\
\hline $\mathrm{NAI} 2$ & Niger, Toula & + & $\mathrm{a}$ & Al & + & $23^{n}$ & $21^{m+1}$ & $\mathrm{nh}$ & $5^{\circ}$ & $18^{\prime}$ & $13^{\prime \prime}$ & 2 \\
\hline NAI3 & Niger, Bonfeba & + & a & Al & + & $23^{N}$ & $21^{m}$ & nh & $\mathrm{nt}$ & $18^{\prime}$ & $13^{\prime \prime}$ & $\mathrm{nt}$ \\
\hline NAI4 & Niger, Bonfeba & + & a & Al & + & $23^{F}$ & $21^{m+1}$ & nh & $\mathrm{nt}$ & $18^{\prime}$ & $13^{\text {r }}$ & $\mathrm{nt}$ \\
\hline NAIS & Niger, Toula & + & a & Al & + & $23^{n}$ & $21^{m / t}$ & nh & $\mathrm{nt}$ & $18^{\prime}$ & $13^{\prime \prime}$ & $\mathrm{nt}$ \\
\hline NAI6 & Niger, Toula & + & a & Al & + & $23^{n}$ & $21^{m t}$ & nh & $\mathrm{nt}$ & $18^{t}$ & $13^{\text {er }}$ & $\mathrm{nt}$ \\
\hline NAI7 & Niger, Toula & + & $\mathrm{a}$ & Al & + & $23^{n}$ & $21^{m r}$ & $\mathrm{nh}$ & nt & $18^{r}$ & $13^{\pi}$ & nt \\
\hline NAI8 & Niger, Bonfeba & + & a & Al & + & $23^{n}$ & $21^{m t}$ & $\mathrm{nh}$ & $\mathrm{nt}$ & $18^{\prime}$ & $13^{a r}$ & $\mathrm{nt}$ \\
\hline NAI9 & Niger, Bonfeba & + & $\mathrm{a}$ & Al & + & $23^{n}$ & $23^{m t}$ & $\mathrm{nh}$ & $\mathrm{nt}$ & $18^{r}$ & $13^{\pi}$ & $\mathrm{nt}$ \\
\hline MAII & Mali, Niono & + & a & A3 & + & $24^{n i}$ & $21^{m+1}$ & $\mathrm{nh}$ & $\mathrm{nt}$ & $18^{\prime}$ & $13^{\prime \prime}$ & $\mathrm{nt}$ \\
\hline $\mathrm{MAI} 2$ & Mali, Niono & + & a & A3 & + & $24^{* i}$ & $21^{m t}$ & nh & $5^{\circ}$ & $18^{\prime}$ & $13^{\prime \prime}$ & 2 \\
\hline MAI9 & Mali, Molodo & + & a & A3 & + & $24^{n i}$ & $22^{\mathrm{mt}}$ & $\mathrm{nh}$ & $\mathrm{nt}$ & $18^{r}$ & $13^{n}$ & 2 \\
\hline \multicolumn{13}{|c|}{ Xanthomonas oryzae pv, oryzicola } \\
\hline CFBP2286 & Malaysia & - & b & - & - & $25^{i}$ & $25^{m t}$ & $17^{\mathrm{m}}$ & $6^{\circ}$ & $19^{r}$ & $14^{\pi}$ & 3 \\
\hline CFBP 2287 & Malaysia & - & b & - & - & $26^{n i}$ & $26^{\mathrm{wt}}$ & $17^{\mathrm{m}}$ & $6^{\circ}$ & $20^{\prime}$ & $14^{\pi}$ & nt \\
\hline UPB 497 & Malaysia & - & b & - & - & $\mathrm{nt}$ & $26^{\mathrm{mt}}$ & nt & $\mathrm{nt}$ & $26^{\prime}$ & $20^{r}$ & 3 \\
\hline BL.S256 & Philippines & - & b & - & - & $\mathrm{nt}$ & nt & nt & nt & $\mathrm{nt}$ & $\mathrm{nt}$ & $\mathrm{nt}$ \\
\hline MAI3 & Mali, Niono & - & b & - & - & $27^{* i}$ & $27^{m+1}$ & $18^{111}$ & $7^{\circ}$ & $21^{r}$ & $15^{\prime \prime}$ & 3 \\
\hline MAI4 & Mali, Niono & - & b & - & - & $28^{n}$ & $28^{m t}$ & $19^{\prime \prime}$ & $8^{\circ}$ & $22^{\prime}$ & $16^{\prime \prime}$ & $\mathrm{nt}$ \\
\hline MAI5 & Mali, Niono & - & b & - & - & $29^{j i}$ & $28^{m+1}$ & $19^{\prime \prime \prime}$ & $9^{\circ}$ & $23^{r}$ & $16^{\text {"f }}$ & 3 \\
\hline MAI6 & Mali, Niono & - & b & - & - & $29^{i j}$ & $28^{m+1}$ & $19^{\prime \prime}$ & $\mathrm{nt}$ & $22^{\prime}$ & $16^{\prime \prime}$ & $\mathrm{nt}$ \\
\hline MAI7 & Mali, Niono & - & b & - & - & $30^{j}$ & $29^{m t}$ & $17^{\mathrm{m}}$ & $10^{\circ}$ & $24^{\prime}$ & $16^{\circ}$ & 3 \\
\hline MAI8 & Mali, Niono & - & b & - & - & $31^{n i}$ & $28^{m t}$ & $17^{\mathrm{m}}$ & $8^{\circ}$ & $22^{r}$ & $17^{\pi}$ & 3 \\
\hline MAIIO & Mali, Niono & - & b & - & . & $27^{* i}$ & $30^{m}$ & $18^{\ln }$ & $8^{\circ}$ & $21^{\prime}$ & $18^{\prime \prime}$ & 3 \\
\hline MAI11 & Mali, Niono & - & b & - & - & $27^{i n}$ & $30^{\mathrm{mt}}$ & $17^{\mathrm{m}}$ & $11^{*}$ & $25^{r}$ & $19^{-r}$ & 3 \\
\hline MAI12 & Mali, Niono & - & b & - & & $27^{i i}$ & $30^{m t}$ & $17^{m}$ & $\mathrm{nt}$ & $25^{\prime}$ & $19^{-4}$ & nt \\
\hline MAI13 & Mali, Niono & - & b & - & - & $27^{n i}$ & $30^{\mathrm{mt}}$ & $17^{\mathrm{m}}$ & $\mathrm{nt}$ & $25^{t}$ & $19^{r}$ & $\mathrm{nt}$ \\
\hline
\end{tabular}

${ }^{a}$ Pathogenicity tests were performed as follows. Column A: leaf clipping inoculation on $O$. sativa var. Nipponbare (susceptible check). + indicates strains inducing typical BB symptoms and - indicates those not inducing symptoms. Column B: leaf infiltration on $O$. sativa var. Nipponbare. a indicates localized lesions and $\mathrm{b}$ indicates spreading translucent and yellow lesions. Column $\mathrm{C}$ : leaf clipping inoculation on a series of near isogenic lines carrying different $\mathrm{Xa}$ genes here and in previous studies (Ogawa et al. 1991). Column D: leaf infiltration of Nicotiana benthamiana leaves; reaction is observed $48 \mathrm{~h}$ after infiltration. + indicates for hypersensitive reaction (HR) and - indicates no HR.

${ }^{\mathrm{b}}$ Restriction fragment length polymorphism (RFLP) groups with the different probes tested and as defined in the text. nt: not tested, nh: no hybridation.

${ }^{\mathrm{c}} \mathrm{PXO}=$ Philippines Xanthomonas oryzae pv. oryzae strains collection, The International Rice Research Institute (IRRI), Los Baños, Philippines; CIAT = Lab Rice Pathology collection, Centro Internacional de Agricultura Tropical, Cali, Colombia; CFBP = Collection Française de Bactéries Phytopathogènes, INRA, Angers, France; NCPPB = National Collection of Plant Pathogenic Bacteria, United Kingdom; BLS = strains of bacterial leaf streak of cereals; MAI NAI and BAI = Xanthomonas oryzae WARDA-IRD (Africa Rice Center- Institut de la Recherche pour le Développement) collection from Mali, Niger, and Burkina, respectively; UPB = Unité de Phytopathologie Bacterial Collection, Louvain La Neuve, Belgium. Strains A, HN, IX, MB, MXO, NXO and XOO were provided by J. Leach as DNA. An asterisk (*) indicates a pathovar reference strain.

${ }^{\mathrm{d}}$ Country and locality where the isolates were collected.

e Amplification fragment length polymorphism (AFLP) groups with significant bootstrap values. 
differences could be observed upon inoculation of African and Asian $X$. oryzae pv. oryzicola strains, all leading to a mild chlorosis response (Fig. 2).

\section{RFLP analyses distinguish}

African $X$. oryzae pv. oryzae strains from Asian ones.

Restriction fragment length polymorphism (RFLP)-based DNA polymorphism analyses were then performed to characterize $X$. oryzae pv. oryzae and $X$. oryzae pv. oryzicola African strains, comparing them with several reference Xanthomonas pathovars. The RFLP probes used in this study enabled us to differentiate the $X$. oryzae strains at the pathovar and infrapathovar level. Probes pJEL101 and pBSavrXa10 were the most discriminative, resolving a high number of haplotypes for both $X$. oryzae pv. oryzae and $X$. oryzae pv. oryzicola strains (Table 1). Probe pJEL101 resolved 31 unique RFLP patterns (haplotypes), seven among $X$. oryzae pv. oryzicola and 24 among $X$. oryzae pv. oryzae strains (Table 1). Haplotypes were clearly distinct when comparing African and Asian $X$. oryzae pv. oryzae strains, African ones exhibiting a lower number of DNA fragments (15 to 16) per strain than did the Asian ones (18 to 25 ) (Fig. 3). Only two haplotypes could be differentiated within $X$. oryzae pv. oryzae African strains, and this enabled us to distinguish strains isolated in Mali in 1980 from those isolated in 2003. Strains originating from Burkina and Niger showed the same pattern as those isolated in Mali and
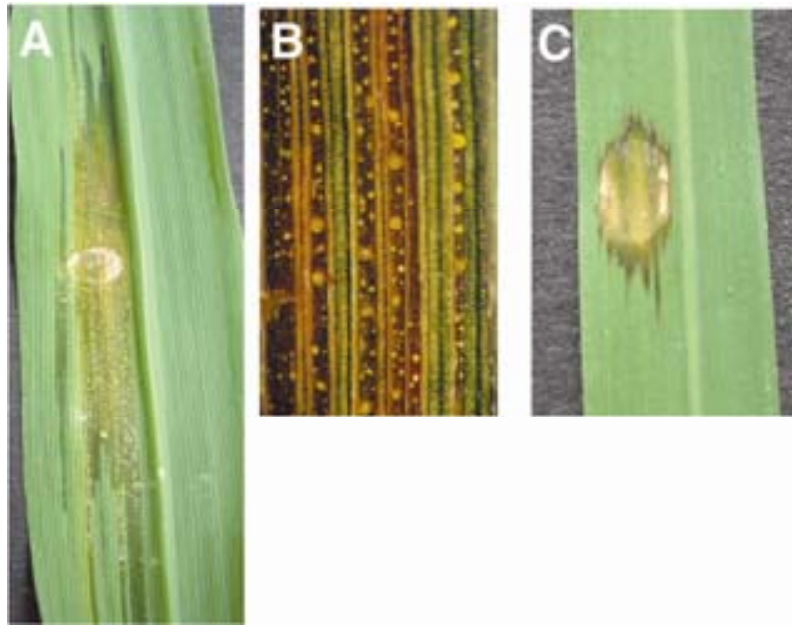

Fig. 1. Disease symptoms observed upon leaf infiltration of the rice susceptible variety Nipponbare ten days after inoculation with A, Xanthomonas oryzae pv. oryzicola MAI3. B, Bacterial leaf streak (BLS) symptoms with droplets of bacterial exudates (close-up of A). C, Symptoms observed after inoculation with $X$. oryzae pv. oryzae BAI4.
Cameroon in the 1980s. Five haplotypes were observed among the African $X$. oryzae pv. oryzicola strains that are clearly distinct from those exhibited by $X$. oryzae pv. oryzicola Asian strains. Finally, none of the Xanthomonas translucens strains hybridized with the pJEL101 probe. Hybridization with probe pBSTnX1 revealed 15 different-sized bands ranging between 15 and $2 \mathrm{~kb}$ (data not shown). X. oryzae pv. oryzae African strains did not hybridize with $\mathrm{pBSTnX} 1$, confirming previous results by Ryba-White and associates (1995). Three haplotypes were observed among $X$. oryzae pv. oryzicola strains with a pattern showing only 1 or 2 bands (data not shown).

Probe pBSavrXa10 resolved 24 haplotypes among $X$. oryzae pv. oryzae and six among $X$. oryzae pv. oryzicola strains (Table 1). Again, haplotypes clearly differentiated $X$. oryzae pv. oryzae African and Asian strains (Fig. 4A). African X. oryzae pv. oryzae strains exhibited four specific and different haplotypes (Fig. 4B), with a lower number of DNA fragments (7 to 8) per strain than Asian $X$. oryzae pv. oryzae ones (10 to 13). Finally, four other conserved T3SS effector ( $a v r B s 2$ and XOO1762) and associated ( $h p a) X$. oryzae pv. oryzae genes ( $h p a F$ and $h p a l)$, as well as avrRxol, which encodes a novel type III effector protein recently characterized in $X$. oryzae pv. oryzicola BLS256, were used as probes. hpal and XOO1762 differentiated X. oryzae strains at the pathovar level. The most discriminative probe was XOO1762, which enabled us to set apart African from Asian $X$. oryzae pv. oryzae strains. Five $X$. oryzae pv. oryzae African strains were tested and were found to exhibit the same haplotype, with four bands ranging from 4 to $12 \mathrm{~kb}$ (data not shown).

Table 2. Reactions of near isogenic lines with single bacterial-resistance genes $(X a)$ against Xanthomonas oryzae pv. oryzae African strains ${ }^{\mathrm{a}}$

\begin{tabular}{llccc}
\hline NILS & Xa-gene & Race A1 $^{\mathbf{b}}$ & Race A2 $^{\mathbf{c}}$ & Race A3 $^{\mathbf{d}}$ \\
\hline IR24 & & $\mathrm{S}$ & $\mathrm{S}$ & $\mathrm{R}$ \\
IRBB3 & $X a 3$ & $\mathrm{~S}$ & $\mathrm{R}$ & $\mathrm{R}$ \\
IRBB4 & $X a 4$ & $\mathrm{R}$ & $\mathrm{R}$ & $\mathrm{R}$ \\
IRBB5 & $x a 5$ & $\mathrm{R}$ & $\mathrm{R}$ & $\mathrm{R}$ \\
IRBB7 & $X a 7$ & $\mathrm{R}$ & $\mathrm{R}$ & $\mathrm{R}$ \\
IRBB8 & $x a 8$ & $\mathrm{MS}$ & $\mathrm{R}$ & $\mathrm{R}$ \\
IRBB10 & $X a 10$ & $\mathrm{~S}$ & $\mathrm{MR}$ & $\mathrm{R}$ \\
IRBB11 & $X a 11$ & $\mathrm{~S}$ & $\mathrm{R}$ & $\mathrm{R}$ \\
IRBB13 & $x a 13$ & $\mathrm{~S}$ & MR & $\mathrm{R}$ \\
IRBB14 & $X a 14$ & $\mathrm{~S}$ & $\mathrm{MR}$ & $\mathrm{R}$ \\
IRBB21 & $X a 21$ & $\mathrm{MS}$ & $\mathrm{MR}$ & $\mathrm{R}$ \\
\hline
\end{tabular}

${ }^{a}$ Resistance or susceptibility of rice plants to $X$. oryzae pv. oryzae is expressed in lesion lengths measured 14 days after inoculation. Resistant (R) $<5 \mathrm{~cm}$, moderately resistant $(\mathrm{MR})=5$ to $10 \mathrm{~cm}$, moderately susceptible $(\mathrm{MS})=10$ to $15 \mathrm{~cm}$, and susceptible $(\mathrm{S})>15 \mathrm{~cm}$.

b Strains NAI1 to NAI9, BAI1, BAI2, BAI3, CFBP1947, CFBP1948.

c Strain BAI4.

${ }^{\mathrm{d}}$ Strains MAI1, MAI2, MAI9, CFBP1949, CFBP1951, CBFP1952.

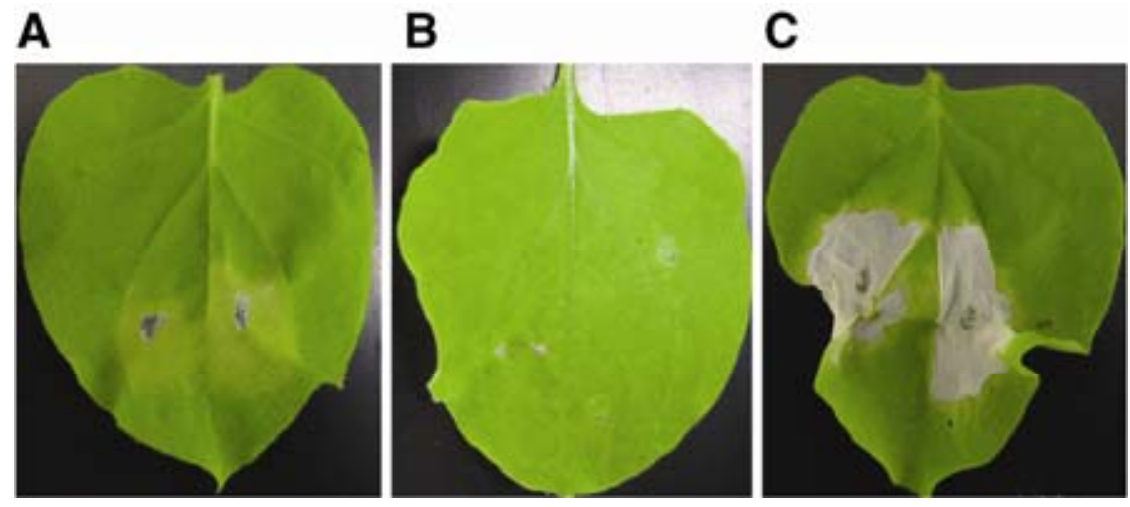

Fig. 2. Xanthomonas oryzae pv. oryzae nonhost hypersensitive response induction assay in Nicotiana benthamiana. Leaves were infiltrated with A, water, B, $X$. oryzae pv. oryzae Asian strain PXO339, and C, X. oryzae pv. oryzae African strain BAI3, at approximately $1 \times 10^{9} \mathrm{CFU} / \mathrm{ml}$. Photographed $48 \mathrm{~h}$ after infiltration. 
Seven haplotypes were obtained among the nine $X$. oryzae pv. oryzicola strains analyzed, which clearly differentiated African and Asian strains. Finally, while avrRxol probe hybridized with Asian $X$. oryzae pv. oryzicola strains, no band could be detected in $X$. oryzae pv. oryzicola African strain, except for MAI3. No homologs could either be detected in $X$. oryzae pv. oryzae Asian or African tested strains (data not shown).

\section{Rep-PCR analyses confirm RFLP results.}

Repetitive sequence-based (Rep)-PCR genomic fingerprints generated with the Rep and enterobacterial repetitive intergenic consensus (ERIC) primers from the entire set of Xanthomonas strains enabled the amplification of 35 and 49 bands, respectively, with sizes ranging from 4,500 to $200 \mathrm{bp}$ (Fig. 5). Rep- and ERIC-PCR-derived DNA fingerprints enabled us to set apart $X$. oryzae pv. oryzae, $X$. oryzae pv. oryzicola, and $X$. translucens strains (Fig. 5 and data not shown). For both $X$. oryzae pv. oryzae and $X$. oryzae pv. oryzicola, they also clearly distinguished African from Asian strains, confirming thereby our RFLP analysis (Fig. 5). ERIC and Rep-PCR defined 18 and 13 haplotypes among $X$. oryzae pv. oryzae strains, respectively (Table 1). ERIC primers allowed the amplification of 7 to 16 different-sized bands per $X$. oryzae pv. oryzicola strain, and seven distinct haplotypes were inferred (Table 1). Amplification with the Rep primers yielded eight haplotypes among $X$. oryzae pv. oryzicola strains with 9 to 19 bands per strain (Fig. 5). Finally, Rep- and ERIC-PCR analysis of $X$. translucens strains defined seven haplotypes (data not shown) clearly distinct from the ones exhibited by $X$. oryzae pv. oryzae and $X$. oryzae pv. oryzicola strains.

\section{$X$. oryzae pv. oryzae African strains form a separate group distant from $X$. oryzae pv. oryzae Asian strains.}

To study the genetic relationships between $X$. oryzae pv. oryzae and $X$. oryzae pv. oryzicola strains, RFLP and Rep-PCR) haplotypes were first analyzed separately by cluster analysis. Dendrograms were generated for the data sets obtained from RFLP analysis (probes pBSavrXa10, pJEL101, and pBSTnX1) and Rep- and ERIC-PCR (data not shown). Visual inspection of these dendrograms suggested that the interrelationships between strains were dependent on the technique used. However, in all cases, obtained groups of strains clearly separated $X$. oryzae pv. oryzae African strains, $X$. oryzae pv. oryzae Asian strains, and $X$. oryzae pv. oryzicola strains. Identical distribution was inferred from the RFLP data obtained with pBSavrXa10, pJEL101, and pBSTnX1 probes. While $X$. oryzae pv. oryzae Asian strains grouped into several clusters (four with pJEL101, seven with pBSavrXa10, and nine with pBSTnX1), X. oryzae pv. oryzae African ones grouped into a single cluster at $70 \%$ similarity (data not shown). X. oryzae pv. oryzicola strains grouped into different clusters (three with pBSavrXa10 and pBSTnX1, five with pJEL101) at $70 \%$ similarity (data not shown), highlighting the high diversity observed among $X$. oryzae pv. oryzicola African strains. The dendrogram generated by ERIC-PCR data defined 16 clusters at $70 \%$ similarity (Fig. 6A), with $X$. oryzae pv. oryzae strains grouping into five clusters, one of them comprising all $X$. oryzae pv. oryzae African strains. Very similarly, RepPCR inferred data defined seven $X$. oryzae pv. oryzae strain clusters, one of which grouped all the African strains (data not shown). ERIC- and Rep-PCR dendrograms grouped $X$. oryzae pv. oryzicola strains into four and five clusters at $70 \%$ similarity, respectively (Fig. 6A). African and Asian strains of X. oryzae pv. oryzicola were grouped in distinct clusters. $X$. translucens strains each grouped in separate clusters, different from $X$. oryzae pv. oryzae and X. oryzae pv. oryzicola ones (Fig. 6A). Finally, the dendrogram derived from all the combined RFLP and Rep-PCR data grouped the strains in 20 clusters at $70 \%$ similarity (Fig. 6B). X. oryzae pv. oryzae strains clustered into nine groups, with one regrouping all African $X$. oryzae pv. oryzae strains. African and Asian $X$. oryzae pv. oryzicola strains were clustered into five groups at $70 \%$ similarity (Fig. 6B). Altogether our data demonstrate that $X$. oryzae pv. oryzae African strains form a separate group genetically distinct from $X$. oryzae pv. oryzae Asian strains.

\section{Fluorescent amplified fragment-length polymorphism (FAFLP) identifies $X$. oryzae pv. oryzae African strains as a separate group.}

To confirm their relatedness, a set of selected strains of $X$. oryzae pv. oryzae and $X$. oryzae pv. oryzicola together with

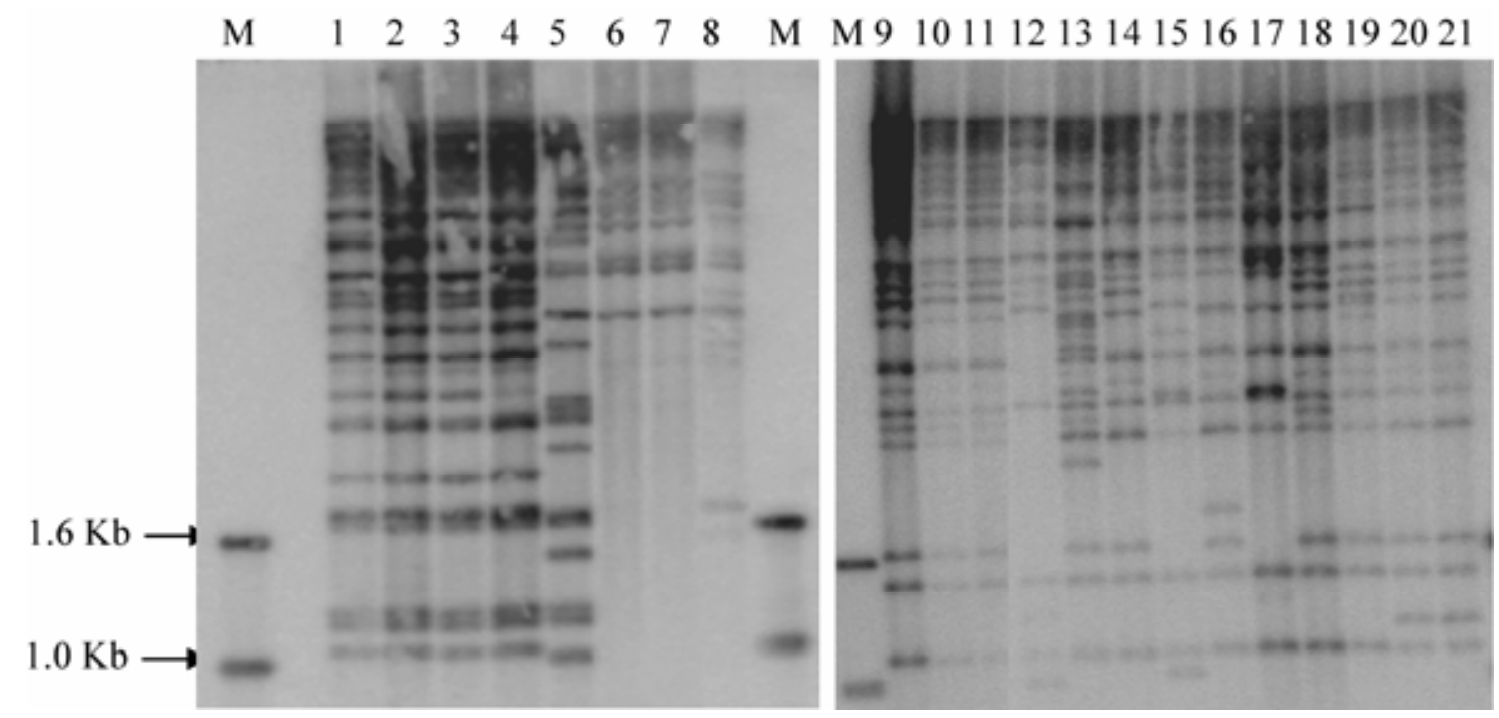

Fig. 3. Hybridization patterns obtained with probe pJEL101 on EcoRI-digested DNA of Xanthomonas oryzae strains, 1, X. oryzae pv. oryzicola CFBP2286; 2, X. oryzae pv. oryzicola MAI13; 3, X. oryzae pv. oryzicola MAI12; 4, X. oryzae pv. oryzicola MAI11; 5, X. oryzae pv. oryzicola MAI10; $6, X$. oryzae pv. oryzae BAI4; 7, X. oryzae pv. oryzae NAI8; 8, X. oryzae pv. oryzae BAI1; 9, X. oryzae pv. oryzae PXO448; 10, X. oryzae pv. oryzae PXO345; 11, X. oryzae pv. oryzae PXO339; 12, X. oryzae pv. oryzae A3857; 13, X. oryzae pv. oryzae A3842; 14, X. oryzae pv. oryzae XOO212; 15, X. oryzae pv. oryzae NXO622; 16, X. oryzae pv. oryzae NXO537; 17, X. oryzae pv. oryzae MXO92; 18, X. oryzae pv. oryzae IXO60; 19, X. oryzae pv. oryzae IXO57; 20, X. oryzae pv. oryzae $\mathrm{HN} 35$; and 21, X. oryzae pv. oryzae $\mathrm{HB} 18 . \mathrm{M}=1-\mathrm{kb}^{+}$ladder. 
strains belonging to other pathovars of Xanthomonas were analyzed by FAFLP. The reproducibility of FAFLP patterns was first evaluated by performing several independent DNA extractions, amplifications, and runs with strains CFBP2532,

\section{A}
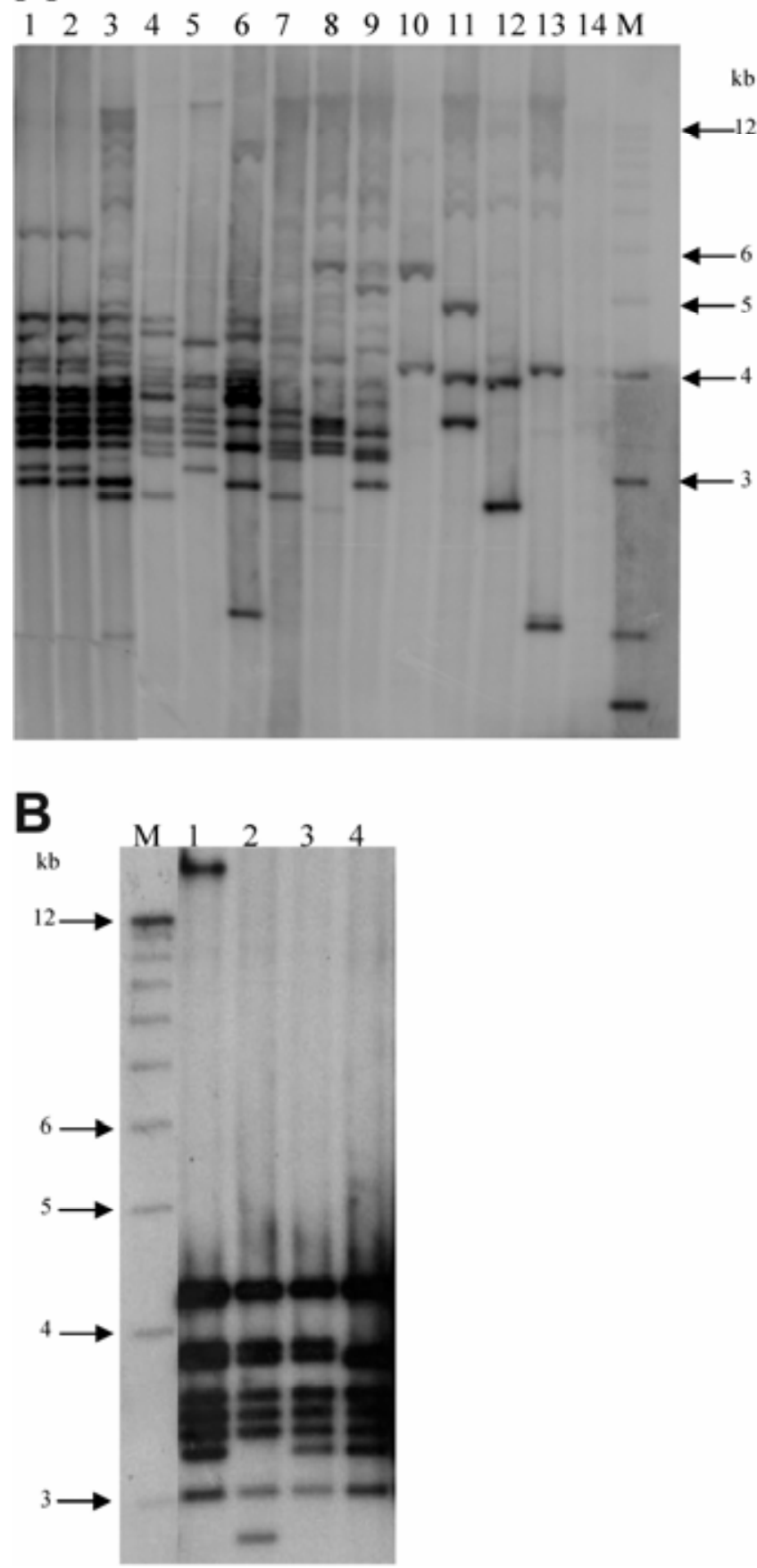

Fig. 4. A, Hybridization patterns obtained with probe pBSavrXa10 on BamHI-digested DNA obtained from the following strains. 1, Xanthomonas oryzae pv. oryzicola CFBP2286; $2, X$. oryzae pv. oryzicola UPB497; 3, X. oryzae pv. oryzicola MAI11; 4, X. oryzae pv. oryzae NXO537; 5, X. oryzae pv. oryzae CFBP1949; 6, X. oryzae pv. oryzae PXO339; 7, X. translucens pv. undulosa UPB513; 8, X. translucens pv. secalis UPB469; 9, X. translucens pv. hordei UPB458; 10, X. translucens pv. arrhenatheri UPB455; 11, X. translucens pv. poae UPB454; 12, X. translucens pv. cerealis UPB453; 13, $X$. translucens pv. phleipratensis UPB 441; and 14, X. translucens pv. graminis UPB437. $\mathrm{M}=1-\mathrm{kb}^{+}$ladder. $\mathbf{B}$, Close-up of the avrXa10 groups obtained with $X$. oryzae pv. oryzae African strains. 1. strain MAI9, group 22 $2^{\text {avr }}$, 2. strain BAI3, group $23^{\text {avr }}$, 3. strain MAI1, group $21^{\text {avr }}$, and 4. strain NAI1, group $24^{\text {avr }}, \mathrm{M}=1-\mathrm{kb}^{+}$ladder.
CFBP2286, and CFBP1121. These strains were then incorporated in the global analysis, and only runs with reproducible patterns were analyzed. Totals of 13 to 42 bands and 23 to 39 bands per strain were obtained with the selective primers $M s p \mathrm{I}+\mathrm{TA}$ and $M s p \mathrm{I}+\mathrm{TG}$, respectively. Size of the bands varied between 50 and $494 \mathrm{bp}$. A total of 453 fragments were analyzed in the global study, each strain producing a unique pattern. FAFLP analysis generated 184 fragments for $X$. oryzae strains, $92 \%$ of these fragments being polymorphic. The number of polymorphic bands among $X$. oryzae pv. oryzae strains (55\%) was similar to that of $X$. oryzae pv. oryzicola strains (49\%). Level of polymorphism was similar among African and Asian $X$. oryzae pv. oryzae strains (53 and 50\%, respectively). The analysis generated 188 fragments for the $X$. transluscens strains, $98 \%$ of them being polymorphic. The intraspecies diversity was not assessed for $X$. axonopodis, $X$. campestris, or $X$. hiacinthi because of a too-low number of strains used in the analysis. All strains of each bacterial species formed separate groups with high bootstrap values (89\% to 100\%) (Fig. 7). Strains of $X$. oryzae separated into three groups with significant bootstrap values (100). X. oryzae pv. oryzae Asian strains clustered in group $1, X$. oryzae pv. oryzae African strains formed group 2 , and $X$. oryzae pv. oryzicola African strains clustered in group 3 together with $X$. oryzae pv. oryzicola Asian strains (Fig. 7 and Table 1). The $X$. oryzae strains were clearly differentiated from the $X$. translucens group, confirming results obtained by RFLP and Rep-PCR.

\section{DISCUSSION}

$X$. oryzae isolates were collected on rice from different countries in West Africa and were characterized in detail by DNA and pathotypic analysis. Our work led to the identification and characterization of new $X$. oryzae pv. oryzae and $X$. oryzae pv. oryzicola strains in Africa. Interestingly, molecular analyses showed that $X$. oryzae pv. oryzae African strains form a group genetically distant from $X$. oryzae pv. oryzae Asian
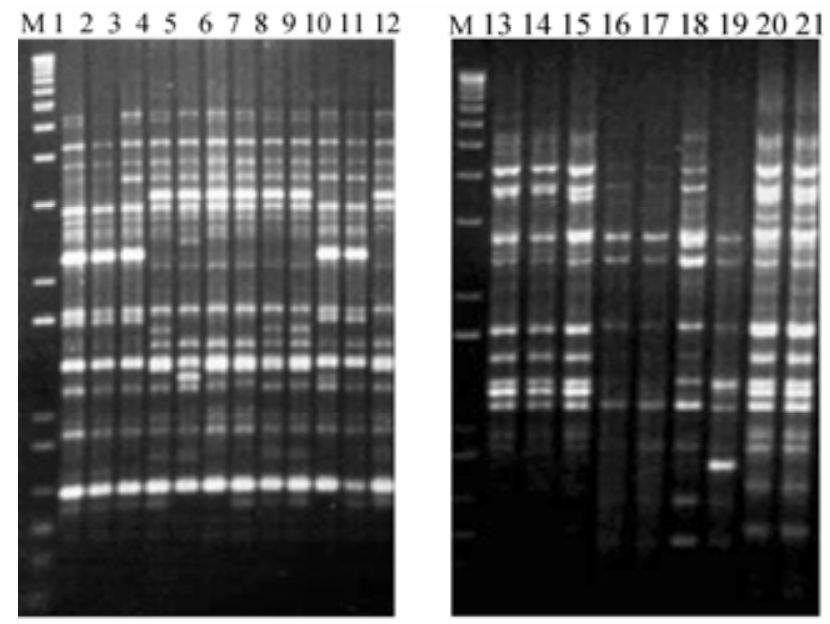

Fig. 5. Polymerase chain reaction (PCR) fingerprint patterns from genomic DNA of Xanthomonas oryzae strains obtained by repetitive-PCR. $1, X$ oryzae pv. oryzae PXO61; 2, X. oryzae pv. oryzae $\mathrm{PXO} 71 ; 3, X$. oryzae pv. oryzae CIAT1186; 4, X. oryzae pv. oryzae PXO86; 5, X. oryzae pv. oryzae PXO99; 6, X. oryzae pv. oryzae CIAT1185, 7, X. oryzae pv. oryzae PXO112; $8, X$. oryzae pv. oryzae PXO145; 9, X. oryzae pv. oryzae PXO280; $10, X$. oryzae pv. oryzae PXO339; 11, X. oryzae pv. oryzae PXO341; 12, X. oryzae pv. oryzae CFBP1951; 13, X. oryzae pv. oryzae CFBP 1947; 14, X. oryzae pv. oryzae CFBP1948; 15, X. oryzae pv. oryzae CFBP1949; 16, X. oryzae pv. oryzicola MAI5; 17, X. oryzae pv. oryzicola MAI6; 18, X. oryzae pv. oryzicola MAI4; 19, X. oryzae pv. oryzicola MAI3; 20, X. oryzae pv. oryzicola MAI1; and 21 X. oryzae pv. oryzicola MAI2. M, 1-kb ladder. 

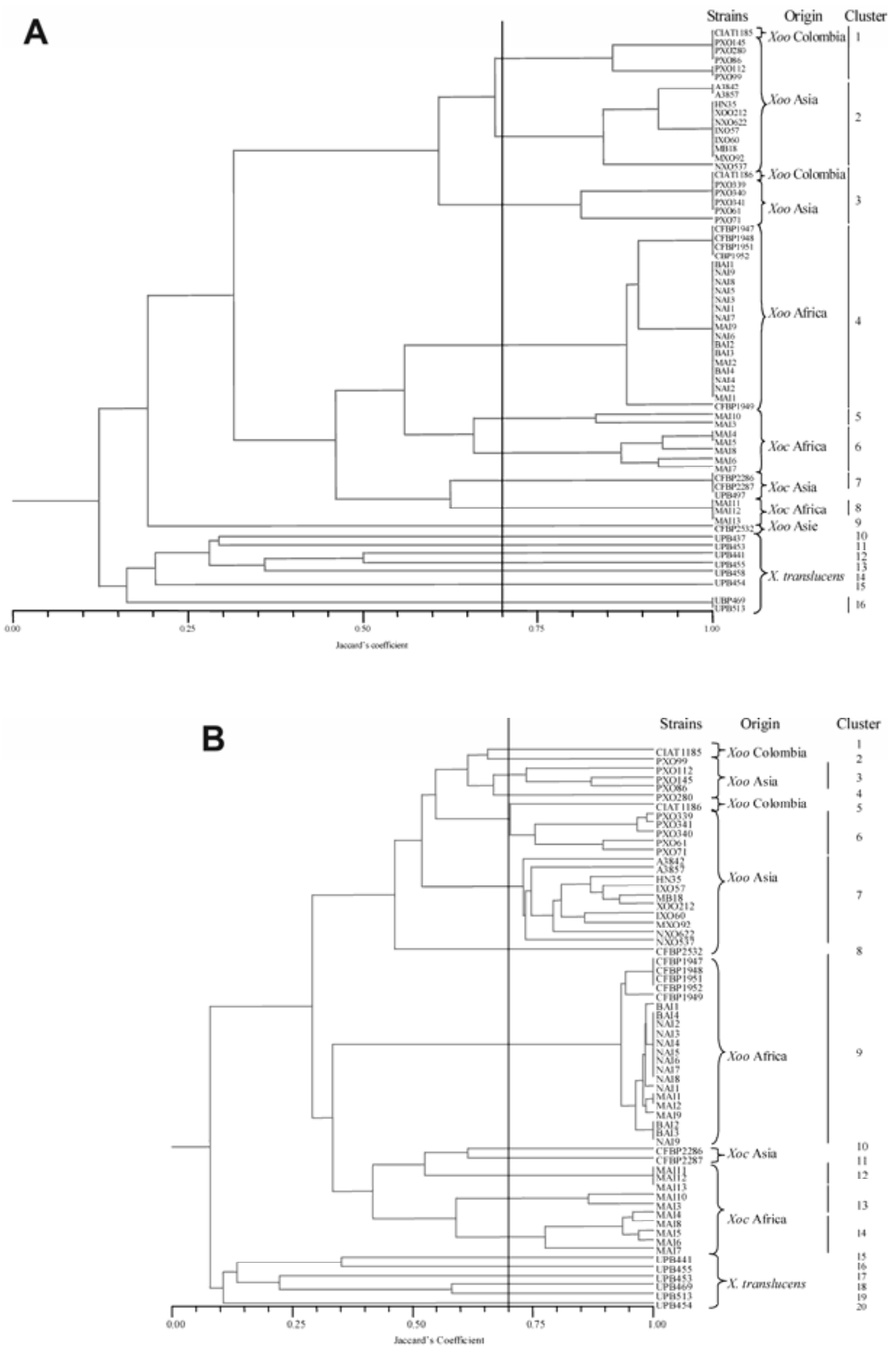

Fig. 6. Dendrograms obtained by cluster analysis using the unweighted pair-group arithmetic mean method by the CLUSTER statistical procedure of SAS, clusters were delineated at an arbitrary level of similarity $=0.70$. A, Enterobacterial repetitive intergenic consensus polymerase chain reaciton (ERIC-PCR). B, Combination of restriction fragment length polymorphism (RFLP) and PCR data. 
strains, while pathotypic analysis led to the identification of three new $X$. oryzae pv. oryzae races. As compared with their Asian relatives, specific features of $X$. oryzae pv. oryzae African strains include i) a reduction of several molecular markers analyzed in this study, i.e., insertion sequence (IS) element IS1112 and TAL ( $a v r B s 3 / p t h A)$ effector genes, ii) the absence of TnX1 (IS1113), an IS found to be conserved in all Asian $X$. oryzae pv. oryzae strains tested so far, and iii) the capacity to induce nonhost HR in N. benthamiana leaves. In addition and to our knowledge, our study constitutes the first report on the characterization of $X$. oryzae pv. oryzicola strains in Africa.

\section{$X$. oryzae pv. oryzae African strains cluster}

in a genetic group distinguishable from Asian ones.

To gain insight into the genetic diversity and evolutionary history of $X$. oryzae isolates in West Africa, DNA polymor- phism characterization based on RFLP, Rep-PCR, and FAFLP analyses were performed. RFLP analyses were achieved using IS and T3SS effector (or associated) genes as probes, since they are presumably phenotype-neutral repetitive elements and involved in host-pathogen interaction, respectively. IS element IS1112 and IS1113 probes were previously found by Nelson and associates (1994) to be the most discriminative for phylogenetic analysis of a collection of $X$. oryzae pv. oryzae strains from the Philippines and, therefore, were used in this study. avrXa10 is an avirulence gene of the avrBs3/pthA multiple gene family, some members of which are essential for $X$. oryzae pv. oryzae full pathogenicity (Hopkins et al. 1992, Niño-Liu et al. 2006). Both IS1112 and avrXa10 probes effectively enabled to differentiate African and Asian strains within $X$. oryzae pv. oryzae and $X$. oryzae pv. oryzicola pathovars, respectively. In addition, new markers were developed using

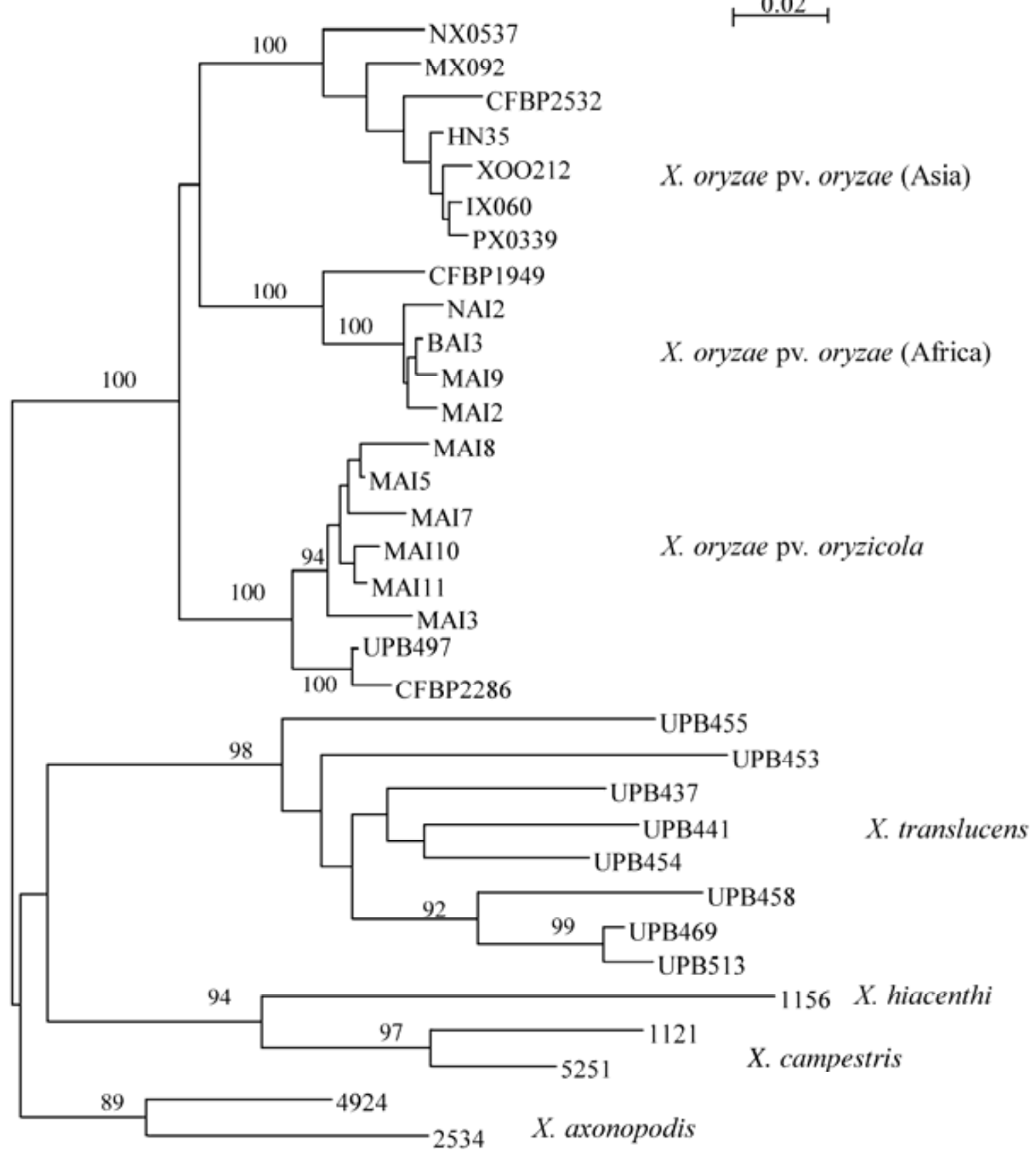

Fig. 7. Dendrogram obtained by fluorescent amplified fragment-length polymorphism (FAFLP) analysis of Xanthomonas strains. Bootstrap values are indicated on the root branching. 
type III effector ( $a v r B s 2, X O O 1762$, and $a v r R x o 1)$ and hrp-associated (hpal and hpaF) genes. XOO1762, which encodes a protein with leucine-rich repeat motifs (Lee et al. 2005), appeared to be the most discriminative at the pathovar level and, relatively, to the geographical origin (Africa or Asia), while the harpin-like protein-encoding gene hpal (Zhu et al. 2000) enabled us to set apart African strains from Asian ones in $X$. oryzae pv. oryzicola. Data were successfully confirmed by Rep-PCR analysis but also by FAFLP. Cluster analysis of the combined data deriving from our DNA polymorphism study revealed $X$. oryzae pv. oryzae African strains as a clear separate genetic group, as compared with reference strains representative of the high degree of genetic diversity among $X$. oryzae pv. oryzae in Asia (Adhikari et al. 1995). Visual inspection of each RFLP data-inferred dendrogram indicated that African $X$. oryzae pv. oryzae strains and $X$. oryzae pv. oryzicola ones always tend to group together on the same branch, while Asian $X$. oryzae pv. oryzae strains all clustered apart. This suggests that African $X$. oryzae pv. oryzae strains are more related to $X$. oryzae pv. oryzicola strains than to $X$. oryzae pv. oryzae Asian ones, although pathogenicity assays undoubtedly discriminated $X$. oryzae pv. oryzae and X. oryzae pv. oryzicola African strains as such.

\section{African X. oryzae pv. oryzae strains display specific features.}

Based on the Asian strains molecular analysis and wholegenome sequencing data, two main characteristics of $X$. oryzae pv. oryzae genome, as compared with other xanthomonads, are i) a higher abundance of IS elements and ii) the prevalence of effector genes of the avrBs3/pthA family (Ochiai et al. 2005; Niño-Liu et al. 2006). With respect to these two criteria, our data show that African $X$. oryzae pv. oryzae strains behave differently, since they carry fewer of both of these two types of genes. Indeed, IS 1112 content is fairly reduced within $X$. oryzae pv. oryzae African strains in comparison to Asian ones and there is no IS1113 (TnX1) copy in their genome, while Asian strains all bear an abundant number of the latter. The role of IS elements in Asian X. oryzae pv. oryzae race evolution was reported earlier and was recently documented in the genome analysis of two Asian $X$. oryzae pv. oryzae strains (Leach et al. 1990, 1992; Lee et al. 2005; Nelson et al. 1994; Ochiai et al. 2005). IS elements are often located near strainspecific genes with distinct GC content, indicating that adjacent genes have been acquired through horizontal gene transfer. The presence of large amounts of transposable elements in a genome may confer adaptive evolution by generating recombination-based rearrangements, as it was hypothesized for Yersinia spp. and Bulkholderia spp. evolution (Chain et al. 2004; Nierman et al. 2004).

Moreover, $X$. oryzae pv. oryzae African strains were all shown to carry up to eight avrBs3/pthA members, while up to 16 copies were detected in some Asian strains (Leach et al. 1990; Yang and Gabriel 1995). avrBs3/pthA-like genes are widely spread within Xanthomonas spp., but this family of effectors seems to have specifically expanded in the $X$. oryzae pv. oryzae genome. The function of each of these effector genes is so far unknown, with some exceptions, and the reason why they are so abundant in $X$. oryzae pv. oryzae remains unclear. Interestingly, recent data by Yang and White (2004) demonstrated that among all the repertoire of TAL effector genes present in a given strain, only one or two play a crucial role as pathogenicity factors. The function of the other gene members is presumed to be to build up a reservoir of genes in the genome or have moderate or minor function in virulence. Indeed, spontaneous recombination has been proved to take place in $X$. oryzae pv. oryzae, albeit with low probability, and to generate new effectors contributing to virulence but not to avirulence (Yang and White 2004). It is hypothesized that the expansion of $a v r B s 3 / p t h A$ genes throughout the genome reflects a strong adaptive pressure imposed on the pathogen population, due to intensive cultivation and selection of the crop (Yang and Gabriel 1994; Yang and White 2005). Consequently, the differences observed between African and Asian $X$. oryzae pv. oryzae strains might be explained by differences with respect to rice cultivation in Africa. The reduced number of avrBs3/pthA genes in African X. oryzae pv. oryzae strains makes them extremely attractive for a functional analysis of this crucial family of effectors in a unique evolutionary context.

Another specific feature of African $X$. oryzae pv. oryzae strains is their capacity to induce a nonhost HR when infiltrated with a high-titer inoculum in $N$. benthamiana leaves, while none of the Asian X. oryzae pv. oryzae (or X. oryzae $p v$. oryzicola) tested ones did. Provided that this phenotype is T3SS-dependent (experiments are in progress in our lab), our data suggest that African $X$. oryzae pv. oryzae strains display one or several specific nonhost HR elicitors, such as type III effectors or harpins. Alternatively, X. oryzae pv. oryzae Asian and $X$. oryzae pv. oryzicola strains may harbor specific effectors inhibiting plant defense responses, as recently demonstrated for several $X$. oryzae pv. oryzae AvrBs3/PthA effectors that suppress nonhost HR in tobacco (Fujikawa et al. 2006) and sofar-unknown $X$. oryzae pv. oryzicola factors inhibiting $R$ genespecific defense responses against $X$. oryzae pv. oryzae in rice (Makino et al. 2006). Nonhost HR-inducing ability would offer an easy tool for the isolation of African $X$. oryzae pv. oryzaespecific effector genes upon gain-of-function complementation assay of an Asian X. oryzae pv. oryzae strain.

\section{African X. oryzae pv. oryzicola strains are deficient for avrRxo1.}

Until our study, avrRxol effector gene was found to be present in all $X$. oryzae pv. oryzicola Asian strains tested, suggesting that it may encode a critical fitness or pathogenicity factor (Zhao et al. 2004a), as is the case, for example, of the Xanthomonas spp.-wide conserved avrBs 2 gene (Kearney and Staskawicz 1990). The identification of X. oryzae pv. oryzicola strains that do not harbor any avrRxol copy (with the exception of strain MAI3) is therefore intriguing and shows how important are population structure and evolution studies prior to the deployment of $R$ gene-containing varieties, as it would be the case for the Rxol nonhost matching $R$ gene. Did African $X$. oryzae pv. oryzicola strains lose avrRxo1? Do they harbor another effector that functionally compensates for avrRxol absence? Clues may be obtained from sequence analysis at the avrRxol locus in MAI3 and nonhybridizing strains as well as upon further population structure studies. A high degree of genetic diversity was observed among African strains of $X$. oryzae pv. oryzicola, similar to what has been inferred from the analysis of $X$. oryzae pv. oryzicola strains isolated in the Philippines (Raymundo et al. 1999). Although visual inspection of RFLP and Rep-PCR data clearly defined specific haplotypes for $X$. oryzae pv. oryzicola African strains, we cannot exclude the possibility that they originated in Asia and were introduced to Africa together with contaminated germplasm.

\section{Virulence assays reveal the existence of three new $X$. oryzae pv. oryzae races among African strains.}

Although $X$. oryzae pv. oryzae African and Asian strains were found to provoke similar symptoms on the susceptible cultivar Nipponbare, virulence assays performed on a set of NILs revealed three $X$. oryzae pv. oryzae African races that do not represent any of the $X$. oryzae pv. oryzae Asian races characterized so far. Race A3 is incompatible on all tested NILs, 
suggesting that A3 strains, which all originate in Mali, harbor an $a v r$ gene that would be specifically recognized by IR24 lines and, consequently, all derived NILs. Indeed, presence of a resistance gene (Xa18) in IR24 has been reported in the literature (Noda et al. 1996). The next challenge will be the characterization of $X$. oryzae pv. oryzae population structure in Africa, and race screening will provide important information to that end, although the NILs used here seem to be welladapted only for African $X$. oryzae pv. oryzae race A1. The development of appropriate NILs in an African background genotype compatible with races A2 and A3 is therefore an essential prerequisite for such study. Race A1 strains show $a v r X a 4$, avrXa5, and $a v r X a 7$ activities on matching Xa4-, $x a 5$-, and $X a 7$-containing lines. Such $R$ genes could be recommended for use in breeding programs but with great caution. For instance, the large-scale and long-term cultivation of varieties carrying $\mathrm{Xa} 4$ resulted in significant shifts in the race frequency of X. oryzae pv. oryzae (Mew et al. 1992; Vera Cruz et al. 2000).

\section{What could be the evolutionary history of $X$. oryzae African strains?}

In many aspects, the African $X$. oryzae pv. oryzae and $X$. oryzae pv. oryzicola strains described in this study differ from their Asian counterparts. Altogether, our data are suggestive of a different evolutionary history for $X$. oryzae pv. oryzae strains originating from West Africa, where the rice species Oryzae glaberrima originated and was domesticated. An important parameter known to shape pathogen population structure evolution and genome dynamic is the intensification of modern agriculture, which is a relatively recent event in Africa, with respect to rice cultivation, as compared with Asia. Indeed, extensive cultivation of rice started only in the 1960s in West Africa and BB was reported 20 years after. In addition, no breeding program for resistance to $\mathrm{BB}$ has ever been conducted in that region. It is therefore likely that, because African $X$. oryzae pv. oryzae strains interactions with cultivated rice lines is rather recent, selective pressure for adaptation to the host is only starting. Although only a very small fraction of the $X$. oryzae pv. oryzae population has been analyzed in our study, it is appealing to speculate about their origin and evolution. $X$. oryzae pv. oryzae African strains were compared with $X$. oryzae pv. oryzae strains from different regions in Asia without finding any common haplotypes or races, but we cannot exclude a possible introduction from another continent through contaminated germplasm. X. oryzae pv. oryzicola strains isolated in Mali were found to be closely related to $X$. oryzae pv. oryzicola strains from Malaysia, suggesting possible transfer between the two continents. Given the striking features of $X$. oryzae pv. oryzae African strains and absence of visible relatedness with $X$. oryzae pv. oryzae Asian strains, a tempting hypothesis is that they are endemic from Africa. Clues to their specificity may certainly be obtained from further genome analysis such as suppression subtractive hybridization, an approach which has been undertaken in our laboratory to compare $X$. oryzae pv. oryzae African and Asian genomes. Sequencing the whole genome of an African $X$. oryzae pv. oryzae strain should also reveal precious information about its origin and evolution. Indeed, complete genome sequences are now available for four $X$. oryzae pv. oryzae Asian strains and, soon, one Asian strain of $X$. oryzae pv. oryzicola, thus facilitating comparative genomic analysis and identification of strainspecific genetic determinants (Niño-Liu et al. 2006).

Our study is a first step towards the characterization of $X$. oryzae pv. oryzae and $X$. oryzae pv. oryzicola populations in West Africa. Extensive pathogen-population analyses are needed and will provide clues to better understand the origin, biology, and evolution of Xanthomonas oryzae pathovars in Africa. Such studies have important implications in rice breeding programs. Resistance genes urgently need to be identified for developing a breeding strategy for durable BB and BLS rice resistance in Africa.

\section{MATERIALS AND METHODS}

\section{Bacterial strains and media.}

$X$. oryzae pv. oryzae, X. oryzae pv. oryzicola, and other Xanthomonas strains were obtained from different origin and collections (Table 1). New strains were isolated in 2003 from diseased leaf samples of rice plants collected in West Africa (Mali, Niger, and Burkina-Faso). The field visit was conducted during the rainy season, when symptoms were visible. Samples were collected from farm and experimental fields and were collected from improved Oryza sativa cultivars, except strain BAI4 from $O$. glaberrima. The leaves were held at $20^{\circ} \mathrm{C}$ until bacterial isolations were conducted. Bacteria were isolated from infected leaves as described (Adhikari et al. 1994). Of each sample, a single bacterial colony was purified on PSA (10 $\mathrm{g}$ of peptone, $10 \mathrm{~g}$ of sucrose, $1 \mathrm{~g}$ of glutamic acid, $16 \mathrm{~g}$ of agar per liter of $\mathrm{H}_{2} \mathrm{O}$ ). The isolates were maintained in $15 \%$ glycerol at $-80^{\circ} \mathrm{C}$. For the DNA extraction, the bacteria were grown overnight in nutrient broth, with shaking, at $28^{\circ} \mathrm{C}$.

\section{Pathogenicity assays.}

All field isolates were tested for virulence on Nipponbare by leaf-clip inoculation. $X$. oryzae pv. oryzae and $X$. oryzae pv. oryzicola strains obtained from international collections were included as control. Experiments were conducted under greenhouse conditions at $26^{\circ} \mathrm{C}$ and $80 \%$ relative humidity. Plants were inoculated at 45 days after sowing, using a clipping method (Kauffman et al. 1973). Bacteria for the inoculum were prepared as described previously (Kauffman et al. 1973). Lesion lengths were measured 15 days postinoculation with a ruler. All plant-inoculation experiments contained two replications with 10 plants and two fully expanded leaves inoculated per plant and were repeated at least three times. Disease reactions were classified according to the mean lesion length (LL) as follows: resistant $(\mathrm{R}), \mathrm{LL}<5 \mathrm{~cm}$; moderately resistant (MR), LL $=5$ to $10 \mathrm{~cm}$; moderately susceptible (MS), LL $=10$ to $15 \mathrm{~cm}$; and susceptible $(\mathrm{S}), \mathrm{LL}>15 \mathrm{~cm}$.

All the strains were also inoculated by leaf infiltration. Leaves of 30-day-old plants (rice variety Nipponbare) were infiltrated with a bacterial suspension (approximately $1 \times 10^{9}$ CFU/ml) prepared from 48-h-old PSA plate cultures with a needleless syringe as previously described (Reimers and Leach 1991). Leaves were infiltrated with sterile water and used as controls. The plants were maintained for 2 days after inoculation in a growth chamber with high relative humidity (90\%). Disease reaction after inoculation was observed at 2-day intervals starting at 5 days after inoculation, and lesion length was measured 10 days after inoculation. All plant-inoculation experiments contained three replications with one plant, two fully expanded leaves inoculated per plant, and two infiltrations per leaf. All the experiments were repeated twice.

The $X$. oryzae pv. oryzae strains were tested on a series of NILs carrying a defined resistance gene backcrossed into the susceptible cultivar IR24 (IR-BB3 [Xa-3], IR-BB4 [Xa-4], IRBB5 [xa-5], IR-BB7 [Xa-7], IR-BB8 [xa-8], IR-BB10 [Xa-10], IR-BB11 [Xa-11], IR-BB13 [Xa-13], IR-BB14 [Xa-14], IRBB21 [Xa-21]), and with IR24 used as a susceptible check. $X$. oryzae pv. oryzae PXO339, PXO341, and PXO99 were used as control. ANOVA statistical analyses were performed for all the assays. 
For $N$. benthamiana nonhost HR induction assays, 3 weekold plants were leaf-infiltrated with a bacterial suspension of approximately $1 \times 10^{9} \mathrm{CFU} / \mathrm{ml}$ and were examined for appearance of nonhost HR-like responses 24 to $48 \mathrm{~h}$ after infiltration. These experiments were reproduced three times on independent individuals.

\section{RFLP.}

Genomic DNA was extracted by the method of Boucher and associates (1985) and concentration was estimated with a spectrophotometer. For each strain, $5 \mu \mathrm{g}$ of total DNA was digested to completion with the enzyme EcoRI, PstI, or BamHI, as described by the manufacturer (New England Biolabs Inc., Saint Quentin, France). Digested DNA underwent electrophoresis in $0.8 \%$ agarose gels in $1 \times$ Tris-borate EDTA (TBE) buffer at 35 $\mathrm{V}$ for $15 \mathrm{~h}$, except for gels of digested BamHI DNA, which were run for $72 \mathrm{~h}$. Fragments were visualized by UV radiation $(302 \mathrm{~nm})$ after staining agarose gels in ethidium bromide $(0.5$ $\left.\mu \mathrm{g} \mathrm{ml}{ }^{-1}\right)$. A size standard $\left(1-\mathrm{kb}^{+}\right.$ladder $)$was included in each gel. Fragments were transferred in alkaline solution onto Hybond $\mathrm{N}^{+}$membrane (Amersham Biosciences, Saclay, Orsay, France), following manufacturer specifications. Different probes were used in this study. Probe pJEL101 is plasmid pUC18 carrying a 2.4-kb EcoRI-HindIII IS1112 fragment derived from $X$. oryzae pv. oryzae (Leach et al. 1990). Probe pBSavrXa10 contains an avrXal0 3.1-kb BamHI fragment in pBluescript (Hopkins et al. 1992). The DNA probe pBSTnX1 (=IS1113) consisted of a 1.05-kb transposable element isolated from $X$. oryzae pv. oryzae (Nelson et al. 1994). Probe pavrRxol contains the avrRxol gene from $X$. oryzae pv. oryzicola (Zhao et al. 2004b). For hpaF, avrBs2, hpal, and XOO1762 analysis, approximately 400-bp amplicons were obtained from $X$. oryzae pv. oryzae BAI3, using primers designed according to one or both available PXO99 or KACC10331 sequences and cloned into pGEM-T Easy vector, leading to probes phpaF, pavrBs2, phpal, and $\mathrm{pXOO1762.} \mathrm{Oligonucleotide} \mathrm{sequences} \mathrm{are} \mathrm{available}$ upon request.

The DNA probes were labeled with $\left[\alpha^{32} \mathrm{P}\right] \mathrm{dCTP}$ by random priming (Megaprime, Amersham Biosciences). Conditions of hybridization and washes were of high stringency. Filters were washed once with $2 \times \mathrm{SSC}(1 \times \mathrm{SSC}$ is $0.15 \mathrm{M} \mathrm{NaCl}$ plus 0.015 $\mathrm{M}$ sodium citrate), $0.1 \%$ sodium dodecyl sulfate (SDS) for 20 min, twice with $1 \times \mathrm{SSC}, 0.1 \%$ SDS for $10 \mathrm{~min}$, and once with $0.1 \times$ SSC, $0.1 \%$ SDS for $20 \mathrm{~min}$. Blots were exposed either on the PhosphorImage machine (Molecular Dynamics Storm, Amersham Biosciences, Saclay , Orsay , France) or on X-ray film (Kodak France, Paris), at $-80^{\circ} \mathrm{C}$ with intensifying screens. Each strain was analyzed at least twice, and the RFLP banding patterns were compared in a single blot to confirm that each pattern was unique.

\section{Rep-PCR analysis.}

The primers used for Rep and ERIC-PCR amplification were: Rep (REP1R-I: 5'-IIIICGICGICATCIGGC-3' and REP2-I: 5'ICGICTTATCIGGCCTAC-3') and ERIC (ERIC1R: 5'-ATGTA AGCTCCTGGGGATTCAC-3' and ERIC2: 5'-AAGTAAGTG ACTGGGGTGAGCG-3'). PCR protocols were as described by Vera Cruz and associates (1996), except for the composition of the buffer (100 mM Tris $\mathrm{HCl}, \mathrm{pH} 8.3,33.5 \mathrm{mM} \mathrm{MgCl}_{2}$, and $500 \mathrm{mM} \mathrm{KCl}$ ). PCR amplifications were performed in an automated thermal cycler, and the program was as described by Vera Cruz and associates (1996). A sample of $12.5 \mu \mathrm{l}$ of amplified PCR product was separated by electrophoresis on $1 \%$ agarose gels in $1 \times \mathrm{TBE}$ buffer at $35 \mathrm{~V}$ for $15 \mathrm{~h}$, stained with ethidium bromide, and then, photographed on a UV transilluminator. PCR amplifications were done at least two times for each strain for confirmation patterns.
Analysis of RFLP and Rep-PCR data.

Banding patterns of hybridization obtained with the RFLP, Rep-PCR and ERIC-PCR were used to compare the relatedness of strains. The presence of a band was coded as 1 (presence) or 0 (absence). A multiple correspondence analysis, generated by the statistic procedure of SAS (release 8.2 [TS2MO] SunOS 5.8 platform; SAS Software, Cary, NC, U.S.A.), was used to determine the positions of the strains on a three-dimensional graph by use of $X^{2}$ distance [Dist ${ }^{2}(\mathrm{k}, \mathrm{l})=\Sigma_{\mathrm{j}}^{\mathrm{J}}=1\left[\left(\mathrm{n}_{\mathrm{kj}} / \mathrm{n}_{\mathrm{k}+}\right)\right.$ - $\left.\left.\left(\mathrm{n}_{\mathrm{lj}} / \mathrm{n}_{\mathrm{l+}}\right)\right]^{2} /\left(\mathrm{n}_{+\mathrm{j}} / \mathrm{n}\right)\right]$. Cluster analysis was done with the unweighted pair-group arithmetic mean method (UPGMA) by the CLUSTER statistical procedure of SAS. The clustering criterion was the average linked method, and the number of clusters was determined by consensus among the two principal clustering statistics, pseudo $F^{2}$ and pseudo $t^{2}$ and the biological data coherence. Average genetic similarities between and within clusters were calculated by the SAS IML procedure. Jaccard's coefficient of similarity $(S=a /[a+b+c])$ was computed from the binary data for all pairwise combinations of strains. We used NTSYS-PC (version 2.10Y) to calculate a similarity matrix, using Jaccard's coefficient. Dendrogram was constructed using the TREE option.

\section{FAFLP analysis.}

The same selected set of $X$. oryzae strains was analyzed by FAFLP. Additionally, few other $X$. oryzae strains were added together with strains representative of the $X$. translucens group, $X$. campestris (CFBP1121 and CFBP5251), X. hyacinthi (CFBP1156), and $X$. axonopodis pv. axonopodis (CFBP4924, CFBP2534). The FAFLP was performed as described by Boudon and associates (2005). The presence and absence of FAFLP fragments were scored in a binary matrix. Similarity matrices using the Jaccard's coefficient were calculated with the dist AFLP program (Mougel et al. 2001). The distance matrices were used to construct dendrograms with the neighbor-joining method (Saitou and Nei 1987). The strength of the tree was assessed by the bootstrap method with the CONSENSE software of PHYLIP (Felsenstein 1993).

\section{ACKNOWLEDGMENTS}

The authors thank J. Leach (Colorado State University, Fort Collins, U.S.A.) for providing us with probes and DNA of $X$. oryzae pv. oryzae strains, N. Vera Cruz (IRRI) for providing NILs varieties, C. Bragard (Université Catholique de Louvain, Louvain La Neuve) for providing with DNAs of $X$. translucens. We thank J. Thome (Centro Internacional de Agricultura Tropical) for his support and M. C. Duque for her help with statistical analyses. We are very grateful to K. Akator and A. Onasaya (Africa Rice Center, Benin), A. Y. Sido, and A. Basso, (Institut National de l'Environnement et de la Recherche Agricole, Burkina, Niger), S. Zaccharie (Institut National de la Recherche Agronomique du Niger, Burkina Faso) and M. M. Coulibaly, Diara, and S. Sara (Institut d'Economie Rurale, Mali) for their help during the field visits. We thank V Charreyron and H. Ennajdaoui for their help during greenhouse and lab experiments. C GGonzalez was supported by a doctoral fellowship awarded by Institut de la Recherche pour le Développement, Département Soutien Formation.

\section{LITERATURE CITED}

Adhikari, T. B. 1994. Phenotypic diversity of Xanthomonas oryzae pv oryzae in Nepal. Plant Dis. 78:68-72.

Adhikari, T. B., Vera Cruz, C. M., Zhang, Q., Nelson, R. J., Skinner, D. Z., Mew, T. W., and Leach, J. E. 1995. Genetic diversity of Xanthomonas oryzae pv. oryzae in Asia. Appl. Environ. Microbiol. 61:966-971.

Adhikari, T. B., Mew, T. W., and Leach, J. E. 1999. Genotypic and pathotypic diversity in Xanthomonas oryzae pv. oryzae in Nepal. Phytopathology 89:687-694

Boucher, C., Barberis, P., Trigalet, A., and Demery, D. 1985. Transposon mutagenesis of Pseudomonas solanacearum: Isolation of Tn5-induced avirulent mutants. J. Gen. Microbiol. 131:2449-2457. 
Boudon, S., Manceau, C., and Notteghem, J. L. 2005. Structure and origin of Xanthomonas arboricola pv. pruni populations causing bacterial spo of stone fruit trees in Western Europe. Phytopathology 95:1081-1088.

Buddenhagen, I. W. 1985. Rice disease evaluation in Madagascar. Int. Rice Comm. Newsl. 34:74-78.

Buttner, D., and Bonas, U. 2002. Getting across-Bacterial type III effector proteins on their way to the plant cell.EMBO (Eur. Mol. Biol. Organ.) J. 21:5313-5322.

Chain, P. S., Carniel, E., Larimer, F. W., Lamerdin, J., Stoutland, P. O., Regala, W. M., Georgescu, A. M., Vergez, L. M., Land, M. L., Motin, V. L., Brubaker, R. R., Fowler, J., Hinnebusch, J., Marceau, M., Medigue, C., Simonet, M., Chenal-Francisque, V., Souza, B., Dacheux, D., Elliott, J. M., Derbise, A., Hauser, L. J., and Garcia, E. 2004. Insights into the evolution of Yersinia pestis through whole-genome comparison with Yersinia pseudotuberculosis. Proc. Natl. Acad. Sci. U.S.A. 101:1382613831.

Chu, Z., Fu, B., Yang, H., Xu, C., Li, Z., Sanchez, A., Park, Y. J., Bennetzen, J. L., Zhang, Q., and Wang, S. 2006. Targeting xa13, a recessive gene for bacterial blight resistance in rice. Theor. Appl. Genet. 112:455-461

Felsenstein, J. 1993. PHYLIP pylogeny inference package, version 3.5c. Department of Genetics, University of Washington, Seattle.

Fujikawa, T., Ishihara, H., Leach, J. E., and Tsuyumu, S. 2006. Suppression of defense response in plants by the avrBs3/pthA gene family of Xanthomonas spp. Mol. Plant-Microbe Interact. 19:342-349.

Gu, K., Yang, B., Tian, D., Wu, L., Wang, D., Sreekala, C., Yang, F., Chu, Z., Wang, G. L., White, F. F., and Yin, Z. 2005. $R$ gene expression induced by a type-III effector triggers disease resistance in rice. Nature 435:1122-1125.

Gurlebeck, D., Thieme, F., and Bonas, U. 2006. Type III effector proteins from the plant pathogen Xanthomonas and their role in the interaction with the host plant. J. Plant Physiol. 163:233-255.

Hopkins, C. M., White, F. F., Choi, S. H., Guo, A., and Leach, J. E. 1992 Identification of a family of avirulence genes from Xanthomonas oryzae pv. oryzae. Mol. Plant-Microbe Interact. 5:451-459.

Kauffman, H. E., Reddy, A. P. K., Hsieh, S. P. H., and Merca S. D. 1973. Improved technique for evaluating resistance of rice varieties to Xanthomonas oryzae. Plant Dis. Rep. 57:537-541

Kearney, B., and Staskawicz, B. J. 1990. Widespread distribution and fitness contribution of Xanthomonas campestris avirulence gene avrBs2. Nature 26:385-386.

Iyer, A. S., and McCouch, S. R. 2004. The rice bacterial blight resistance gene $x a 5$ encodes a novel form of disease resistance. Mol. PlantMicrobe Interact. 17:1348-1354

Jeung, J. U., Heu, S. G., Shin, M. S., Vera Cruz, C. M., and Jena, K. K. 2006. Dynamics of Xanthomonas oryzae pv. oryzae populations in Korea and their relationship to known bacterial blight resistance genes. Phytopathology 96:867-875.

Leach, J. E., White, F. F., Rhoads, M. L., and Leung, H. A. 1990. Repetitive DNA sequence differentiates Xanthomonas campestris pv. oryzae from other pathovars of $X$. campestris. Mol. Plant-Microbe Interact. 3:238-246.

Leach, J. E., Rhoads, M. L., Vera Cruz, C. M., White, F. F., Mew, T. W., and Leung, H. 1992. Assessment of genetic diversity and population structure of Xanthomonas oryzae pv. oryzae with a repetitive DNA element. Appl. Environ. Microbiol. 58:2188-2195.

Lee, B. M., Park, Y. J., Park, D. S., Kang, H. W., Kim, J. G., Song, E. S., Park, I. C., Yoon, U. H., Hahn, J. H., Koo, B. S., Lee, G. B., Kim, H., Park, H. S., Yoon, K. O., Kim, J. H., Jung, C. H., Koh, N. H., Seo, J. S., and Go, S. J. 2005. The genome sequence of Xanthomonas oryzae pathovar oryzae KACC10331, the bacterial blight pathogen of rice. $\mathrm{Nu}$ cleic Acids Res. 33:577-586.

Li, Z. K., Arif, M., Zhong, D. B., Fu, B. Y., Xu, J. L., Domingo-Rey, J., Ali, J., Vijayakumar, C. H. M., Yu, S. B., and Khush, G. S. 2006. Complex genetic networks underlying the defensive system of rice (Oryza sativa L.) to Xanthomonas oryzae pv. oryzae. Proc. Natl. Acad. Sci. U.S.A. 103:7994-7999

Makino S, Sugio, A., White, F., and Bogdanove, A. J. 2006. Inhibition of resistance gene-mediated defense in rice by Xanthomonas oryzae pv. oryzicola. Mol. Plant-Microbe Interact. 19:240-249.

Mew, T. W., Alvarez, A. M., Leach, J. E., and Swings, J. 1993. Focus on bacterial blight of rice. Plant Dis. 77:5-12.

Mougel, C., Teyssier, S., D’Angelo, C., Groud, K., Neyra, M., SidiBoumedine, K., Cloeckaert, A., Peloille, M., Baucheron, S., ChaslusDancla, E., Jarraud, S., Meugnier, H., Forey, F., Vandenesch, F., Lina, G., Etienne, J., Thioulouse, J., Manceau, C., Robbe, P., Nalin, R., Briolay, J., and Nesme, X. 2001. Experimental and theoretical evaluation of typing methods based upon random amplification of genomic restriction fragments AFLP for bacterial population genetics. Genet. Sel. Evol. 33:S319-S338.
Nelson, R. J., Baraoidan, M. R., Vera-Cruz, C. M., Yap, I. V., Leach, J. E., Mew, T. W., and Leung, H. 1994. Relationship between phylogeny and pathotype for the bacterial blight pathogen of rice. Appl. Environ. Microbiol. 60:3275-3283.

Nierman, W. C., DeShazer, D., Kim, H. S., Tettelin, H., Nelson, K. E., Feldblyum, T., Ulrich, R. L., Ronning, C. M., Brinkac, L. M., Daugherty, S. C., Davidsen, T. D., Deboy, R. T., Dimitrov, G., R Dodson, J., Durkin, A. S., Gwinn, M. L., Haft, D. H., Khouri, H., Kolonay, J. F., Madupu, R., Mohammoud, Y., Nelson, W. C., Radune, D., C. Romero, M., Sarria, S., Selengut, J., Shamblin, C., Sullivan, S. A., White, O., Yu, Y., Zafar, N., Zhou, L., and Fraser, C. M. 2004. Structural flexibility in the Burkholderia mallei genome. Proc. Nat. Acad. Sci. U.S.A. 101:14246-14251.

Niño-Liu, D. O., Ronald, P. C., and Bogdanove, A. J. 2006. Xanthomonas oryzae pathovars: Model pathogens of a model crop. Mol. Plant Pathol. 7:303-324.

Noda, T., Yamamoto, T., Kaku, H., and Horino, O. 1996. Geographical distribution of pathogenic races of Xanthomonas oryzae pv. oryzae in Japan in 1991 and 1993. Ann. Phytopathol. Soc. Jpn. 62:549-553.

Ochiai, H., Inoue, Y., Takeya, M., Sasaki, A., and Kaku, H. 2005. Genome sequence of Xanthomonas oryzae pv. oryzae suggests contribution of large numbers of effector genes and insertion sequences to its race diversity. Jpn. Agric. Res. Quart. 39:275-287.

Ogawa, T., Busto, G. A. J., Tabien, R. E., Romero, G.O., Endo, N., and Khush, G. S. 1991. Grouping of rice cultivars based on reaction pattern of Philippine races of bacterial blight pathogen Xanthomonas campestris pv. oryzae. Jpn. J. Breed. 41:109-120.

Rademaker, J. L., Hoste, B., Louws, F. J., Kersters, K., Swings, J., Vauterin, L., Vauterin, P., and de Bruijn, F. J. 2000. Comparison of AFLP and rep-PCR genomic fingerprinting with DNA-DNA homology studies: Xanthomonas as a model system. Int. J. Syst. Evol. Microbiol. 50:665-77

Raymundo, A. K., Briones, A. M. Jr., Ardales, E. Y., Perez, M. T., Fernandez, L. C., Leach, J. F., Mew, T. W., Ynalvez, M. A., McLaren, C. G., and Nelson, R. J. 1999. Analysis of DNA polymorphism and virulence in Philippine strains of Xanthomonas oryzae pv. oryzicola. Plant Dis. 83:434-440.

Reimers, P. J., and Leach, J. E. 1991. Race-specific resistance to Xanthomonas oryzae pv. oryzae conferred by bacterial blight resistance gene $\mathrm{Xa}-10$ in rice Oryza sativa involves accumulation of a lignin-like substance in host tissues. Physiol. Mol. Plant Pathol. 38:39-56.

Ryba-White, M., Notteghem, J. L., and Leach, J. E. 1995. Comparison of Xanthomonas oryzae pv. oryzae strains from Africa, North America, and Asia by restriction fragment length polymorphism analysis. Intl. Rice Res. Notes 20:25-26.

Saitou, N., and Nei, M. 1987. The neighbour-joining method: A new method for reconstructing phylogenetic trees. Mol. Biol. Evol. 4:406425.

Shen, Y., and Ronald, P. 2002. Molecular determinants of disease and resistance in interactions of Xanthomonas oryzae pv. oryzae and rice. Microbes Infect. 4:1361-1367.

Song, W. Y., Wang, G. L., Chen, L. L., Kim, H. S., Pi,L. Y., Holsten, T., Gardner, J., Wang, B., Zhai, W. X., Zhu, L. H., Fauquet, C., and Ronald, P. 1995. A receptor kinase-like protein encoded by the rice disease resistance gene, Xa21. Science 270:1804-1806.

Sun, X., Cao, Y., Yang, Z., Xu, C., Li, X., Wang, S., and Zhang, Q. 2004. $X a 26$, a gene conferring resistance to Xanthomonas oryzae pv. oryzae in rice, encodes an LRR receptor kinase-like protein. Plant J. 37:517-527.

Swings, J., Van Den Mooter, M., Vauterin, L., Hoste, B., Gillis, M., Mew, T. W., and Kersters, K. 1990. Reclassification of the causal agents of bacterial blight Xanthomonas campestris pathovar oryzae and bacterial leaf streak Xanthomonas campestris pathovar oryzicola of rice as pathovars of Xanthomonas oryzae new. Int. J. Syst. Bacteriol. 40:309-311.

Vera Cruz, C. M., Ardales, E. Y., Skinner, D. Z., Talag, J., Nelson, R. J., Louws, F. J, Leung, H., Mew, T. W., and Leach, J. E. 1996. Measurement of haplotypic variation in Xanthomonas oryzae pv. oryzae within a single field by rep-PCR and RFLP analyses. Phytopathology 86:13521359

Vera Cruz, C. M., Bai, J., Ona, I., Leung, H., Nelson, R. J., Mew, T. W., and Leach, J. E. 2000. Predicting durability of a disease resistance gene based on an assessment of the fitness loss and epidemiological consequences of avirulence gene mutation. Proc. Natl. Acad. Sci. U.S.A. 97:13500-13505.

Yang, B., Zhu, W., Johnson, L.B., and White, F.F. 2000. The virulence factor AvrXa7 of Xanthomonas oryzae pv. oryzae is a type III secretion pathway-dependent nuclear-localized double-stranded DNA-binding protein. Proc. Natl. Acad. Sci. U.S.A. 97:9807-9812

Yang Y., and Gabriel, D. W. 1995. Intragenic recombination of a single plant pathogen gene provides a mechanism for the evolution of new host specificities. J. Bacteriol. 177:4963-4968. 
Yang, B., and White, F. F. 2004. Diverse members of the AvrBs3/PthA family of type III effectors are major virulence determinants in bacterial blight disease of rice. Mol. Plant-Microbe Interact. 17:1192-1200.

Yang, B., Sugio, A., and White, F. F. 2005. Avoidance of host recognition by alterations in the repetitive and C-terminal regions of AvrXa7, a type III effector of Xanthomonas oryzae pv. oryzae. Mol. Plant-Microbe Interact. 18:142-149.

Yoshimura, S., Yamanouchi, U., Katayose, Y., Toki S., Wang, Z. X., Kono, I., Kurata, N., Yano, M., Iwata, N., and Sasaki, T. 1998. Expression of $\mathrm{Xa1}$, a bacterial blight-resistance gene in rice, is induced by bacterial inoculation. Proc. Natl. Acad. Sci. U S A. 95:1663-1668.

Zhao, B., Ardales, E. Y., Raymundo, A., Bai, J., Trick, H. N., Leach, J. E. and Hulbert, S. H. 2004a. The avrRxo1 gene from the rice pathogen
Xanthomonas oryzae pv. oryzicola confers a nonhost defense reaction on maize with resistance gene Rxol. Mol. Plant-Microbe Interact. 17:771-779.

Zhao, B., Ardales, E., Brasset, E., Claflin, L. E., Leach, J. E., and Hulbert, S. H. 2004b. The Rxol/ Rbal locus of maize controls resistance reactions to pathogenic and non-host bacteria. Theor. Appl. Genet. 109:7179.

Zhao, B., Lin, X., Poland, J., Trick, H., Leach, J., and Hulbert, S. H. 2005. A maize resistance gene functions against bacterial streak disease in rice. Proc. Natl. Acad. Sci. U.S.A. 102:15383-15388.

Zhu, W., MaGbanua, M. M., and White, F. F. 2000. Identification of two novel hrp-associated genes in the hrp gene cluster of Xanthomonas oryzae pv. oryzae. J. Bacteriol. 182:1844-1853. 